UC-66

\title{
$B 83^{20}$
}

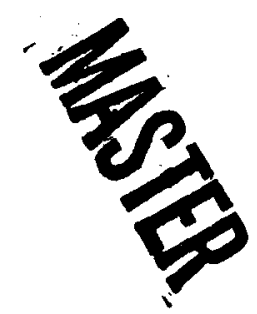

\section{Geothermal Potential on Kirtland Air Force Base Lands, Bernalillo County, New Mexico 乏}

P. R. Grant, Jr

Energy Resources Exploration, Inc Albuquerque, NM

Prepared by Sandia National Laboratories, Albuquerque, New Mexico 87185 and Livermore, California 94550 for the United States Department of Energy under Contract DE-AC04-76DP00789

Printed October 1981

Prepared for Sandia National Laboratories under Contract No. 62-9994 


\section{DISCLAIMER}

This report was prepared as an account of work sponsored by an agency of the United States Government. Neither the United States Government nor any agency Thereof, nor any of their employees, makes any warranty, express or implied, or assumes any legal liability or responsibility for the accuracy, completeness, or usefulness of any information, apparatus, product, or process disclosed, or represents that its use would not infringe privately owned rights. Reference herein to any specific commercial product, process, or service by trade name, trademark, manufacturer, or otherwise does not necessarily constitute or imply its endorsement, recommendation, or favoring by the United States Government or any agency thereof. The views and opinions of authors expressed herein do not necessarily state or reflect those of the United States Government or any agency thereof. 


\section{DISCLAIMER}

Portions of this document may be illegible in electronic image products. Images are produced from the best available original document. 
Issued by Sandia National Laboratories, operated for the United States Department of Energy by Sandia Corporation.

\section{NOTICE}

This report was prepared as an account of work sponsored by the United States Government. Neither the United States nor the Department of Energy, nor any of their employees, nor any of their contractors, subcontractors, or their employees, makes any warranty, express or implied, or assumes any legal liability or responsibility for the accuracy, completeness or usefulness of any information, apparatus, product or process disclosed, or represents that its use would not infringe privately owned rights.

Printed in the United States of America

Available from:

National Technical Information Service

U. S. Department of Commerce

5285 Port Royal Road

Springfield, Virginia 22161

Price: Printed Copy $\$ 7.00 ;$ Microfiche $\$ 3.50$ 


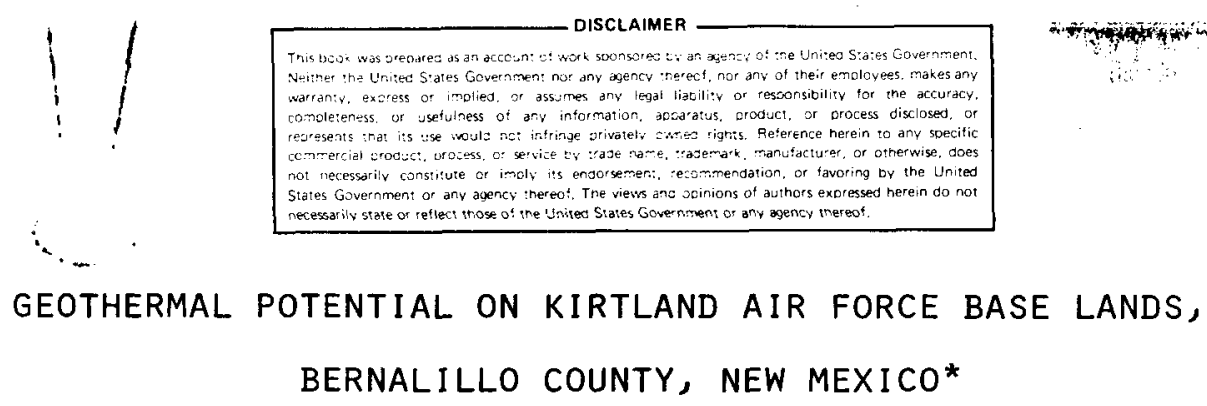

SAND81-7141

P. R. (Bob) Grant, Jr.

Consulting Geologist

Albuquerque, New Mexico 87112

\section{Abstract}

Public policy expressed in a number of national directives in recent years stresses the conservation of conventional fuel supplies, a switch to alternate fuels, and the application of advanced energy technologies at federal installations. Natural gas currently furnishes 85 to 95 percent of the average $94 \times 10^{6} \mathrm{Btu} / \mathrm{hr}$ energy requirements for space heating and cooling at Kirtland Air Force Base. Studies of alternatives to the use of natural gas at the base include examination of the geothermal option.

Four of North America's major physiographic provinces coalesce in central New Mexico on or near Kirtland AFB. Their junction is identified throughout much of this region by a tectonic depression occupied by the Rio Grande that is structurally complex, stratigraphically and hydrologically unique, and coincides with geologically recent volcanic centers. This trough, the Rio Grande rift, has been identified as a major geothermal resource area. The western part of Kirtland AFB is in the Albuquerque Basin segment of the Rio Grande rift.

Virtually all of the principal tectonic events that formed the east side of the Rio Grande rift, the Albuquerque Basin, and the adjoining Sandia, Manzanita, and Manzano mountain ranges occurred on and have profoundly affected Kirtland AFB lands. Large deposits of travertine were located at the junction of two major fault systems on the base. These support a premise that a preexisting hydrologic system coursed meteoric water through the thick, relatively unconsolidated valley fill sediments of the Rio Grande rift's late Tertiary Santa Fe formation where it was subjected to substantially warmer temperatures at depth and then rose to the surface by convection currents along the master faults.

Extensive sampling and geochemical analysis of groundwater in and near the base disclosed no significant geothermal parameters. However, structural conditions and current hydrologic regimes strongly suggest that thermal waters would be masked by near surface, low temperature meteoric water originating as rain and snowfall in the nearby mountains.

Controlled source audio-magnetotelluric (CSAMT) electromagnetic techniques, refraction seismic experiments, and gravity traverses were utilized on the base. These, together with published geophysical

ÆPrepared for Sandia National Laboratories, Albuquerque, New Mexico, under Consultant Agreement No. 62-9994. 
information that presents evidence for a shallow magma body beneath the Albuquerque Basin; favorable terrestrial heat flow, water chemistry, and shallow temperature gradient holes on the nearby mesa west of the Rio Grande; interpretation of regional gravity data; and geological data from nearby deep wells tend to confirm structural, stratigraphic, and hydrologic conditions favorable for developing an extensive intermediate to high-temperature hydrothermal regime on portions of Kirtland AFB lands where intensive land use occurs.

Two possible exploration and development scenarios are presented. One involves drilling a well to a depth of 3,000 to $5,000 \mathrm{ft}$ (914 to $1,524 \mathrm{~m})$ to test the possibility of encountering higher than normal water temperatures on the basinward side of the faults underlying the travertine deposits. The other is to conduct limited reflection seismograph surveys in defined areas on the base to determine the depth to basement (granite) and thickness of the overlying, unconfined, water. filled, relatively unconsolidated sand and gravel aquifer. Existing data indicates that wells drilled into this aquifer would supply water with temperatures ranging from $260^{\circ} \mathrm{F}$ to $460^{\circ} \mathrm{F}\left(127^{\circ} \mathrm{C}\right.$ to $\left.238^{\circ} \mathrm{C}\right)$ at depths of 10,000 to $20,000 \mathrm{ft}(3,281$ to $6,562 \mathrm{~m})$. Certain assumptions suggest that a geothermal energy system for Kirtland AFB costing up to $\$ 10,000,000$ would be cost competitive with other alternative systems such as coal. 


\section{ACKNOWLEDGMENTS}

Funding and logistical support for this effort came from Sandia National Laboratories and the U. S. Air Force. Coordinating the project were Richard K. Traeger, Manager, Geo Energy Technology Department II, for Sandia and Capt. William J. Barattino, Chief, DOE-AFESC Liaison, Albuquerque Operations office for the Air Force.

Sandia geologist Linda Riddle implemented procedures during the summer of 1980 to obtain and review the geologic literature of the area, gather water samples from springs and wells for geochemical analysis, acquire base maps of the area from Sandia and Air Force sources, secure the necessary approvals for conducting geologic investigations on the base, and coordinate the efforts of others who participated in this project. Her active involvement and contribution to data acquisition and interpretation is summarized in "Geothermal studies at Kirtland Air Force Base, Albuquerque, New Mexico" (Riddle and Grant, 1981).

Lawrence $\mathrm{H}$. Jaksha of the USGS Albuquerque Seismological Laboratory conducted refraction geophysical experiments that were coordinated with the scheduled detonation of explosives near the base by the New Mexico Engineering Research Institute (NMERI; formerly Civil Engineering Research Facility/CERF), a branch of the University of New Mexico (UNM) Department of Engineering under contract to the Air Force Weapons Laboratory. Edward L. Tremba, NMERI geologist, assisted with this effort to obtain subsurface structural and stratigraphic information. Mark D. Parker, a graduate student in the UNM Department of Geology, conducted gravity seismological surveys within the base as part of the program (Appendix A). SNL geophysicists L. C. Bartel, C. W. Ray, R. D. Jacobson, and P. M. Drozda used a controlled source audio-magnetotelluric (CSAMT) electromagnetic (EM) geophysical prospecting technique to identify a major fault on the base.

Excellent cooperation was received from all military and civilian personnel on the base when it was requested during the course of the investigation. 


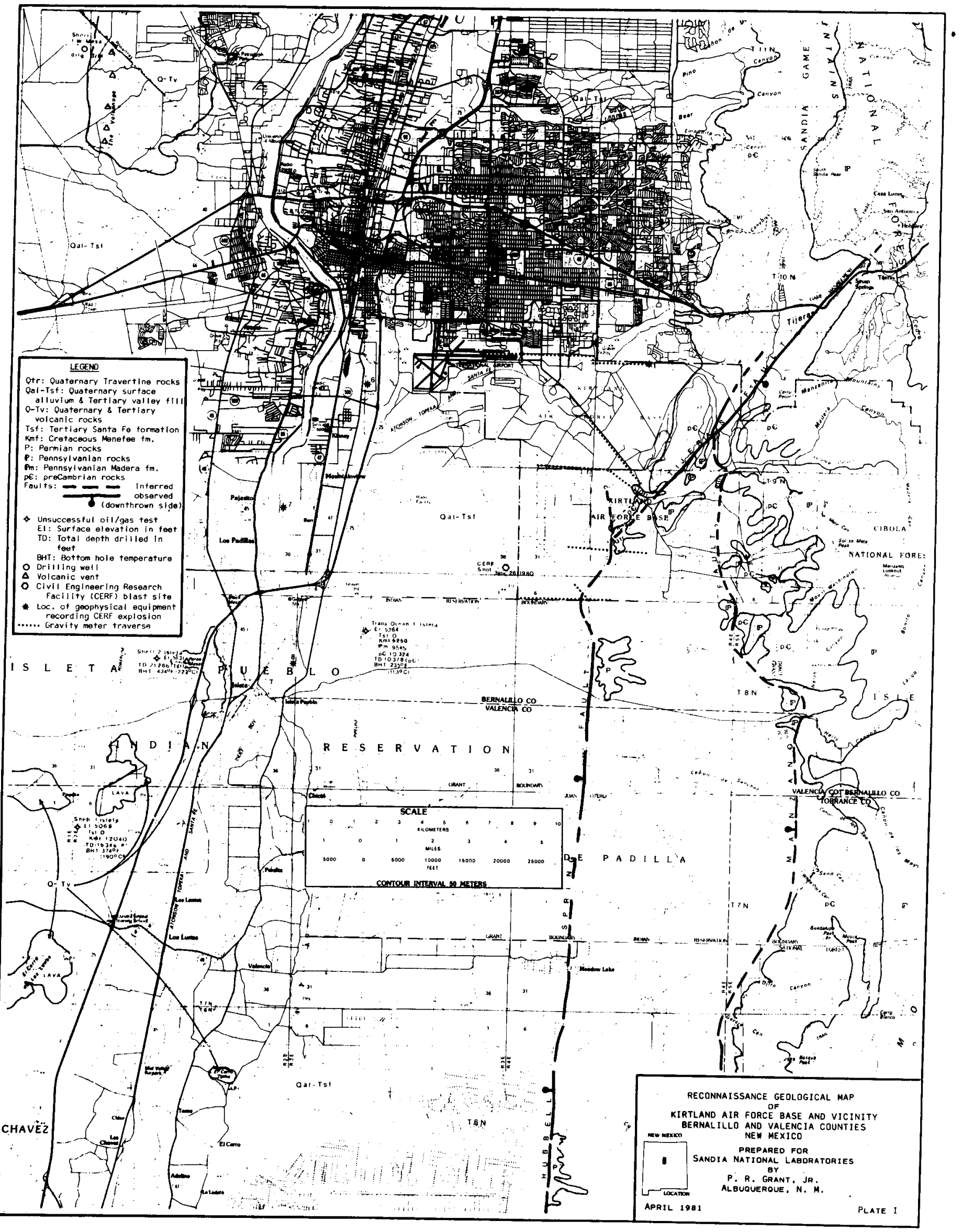


Abstract. . . . . . . . . . . . . . . . . . . . 1

Acknowledgments . . . . . . . . . . . . . . . . . . . . 3

Introduction. . . . . . . . . . . . . . . . . . . 7

objectives. . . . . . . . . . . . . . . . . . . . . . 8

Procedures. . . . . . . . . . . . . . . . . 8

Regional Geologic Setting . . . . . . . . . . . . . . . . . 10

Previous work . . . . . . . . . . . . . . . . . . . I0

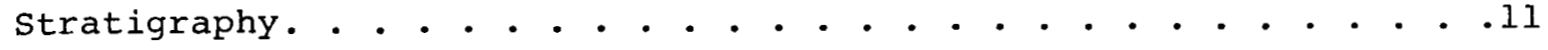

structure . . . . . . . . . . . . . . . . . . . . 11

Regional Geologic History. . . . . . . . . . . . . . . . . Il

Subsurface Relationships . . . . . . . . . . . . . . . .14

Earthquakes. . . . . . . . . . . . . . . . . . . . 15

Volcanism...........................16

The Rio Grande Rift . . . . . . . . . . . . . . . . . . . . I6

Albuquerque Basin . . . . . . . . . . . . . . . . . . . . . . . . . . .

Kirtland Air Force Base . . . . . . . . . . . . . . . . 20

Physiographic Provinces. . . . . . . . . . . . . . . 20

Tijeras fault. . . . . . . . . . . . . . . . . . . . . . 21

Hubbell Springs Fault. . . . . . . . . . . . . . . . . . 21

Sandia Fault... . . . . . . . . . . . . . . . . 25

The Travertine Hills... . . . . . . . . . . . . 28

Temperature. . . . . . . . . . . . . . . . . . . . .31

Depth to Basement. . . . . . . . . . . . . . . . . . .34

Conclusions . . . . . . . . . . . . . . . . . . . . . . . . . . .

Recommendations . . . . . . . . . . . . . . . . . . . . .40

Shallow Temperature Gradient Wells... . . . . . . . . .40

Reflection Seismic Survey. . . . . . . . . . . . . . . 40

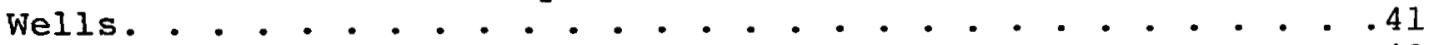

Costs. . . . . . . . . . . . . . . . . . . . 42

Cost Benefits. . . . . . . . . . . . . . . . . .42

References. . . . . . . . . . . . . . . . . . . . . . 44

Appendix A. . . . . . . . . . . . . . . . . . . . . . . . 49

Appendix B. . . . . . . . . . . . . . . . . . . . . 61 
Plate 1: Reconnaissance geologic map of Kirtland AFB and vicinity, Bernalillo and Valencia Counties, New Mexico.. . . . . . . . . . . . . . . . 4

Fig. 1 Location map showing relationship of Kirtland AFB to geologic and geographic features of the Rio Grande Rift. . . . . . . . . . . . . . . 9

Fig. 2 Tectonic map of the Rio Grande Rift system in New Mexico...................... . 18

Fig. 3 Geologic map of the Albuquerque-Kirtland AFB Area. . . . . . . . . . . . . . . . . . 22

Fig. 4 Preliminary complete Bouguer anomaly gravity map of part of the Rio Grande Rift in northcentral New Mexico . . . . . . . . . . . . 24

Fig. 5 Controlled source audio-magnetotelluric (CSAMT) electromagnetic (EM) geophysical experiment . . . . . .26

Fig. 6 Schematic east-west cross section of the Albuquerque Basin near the south boundary of Kirtland AFB lands. . . . . . . . . . . . . . . 32

Fig. 7 Deep wells in the vicinity of Albuquerque . . . . . . .35

Fig. 8 Elevation of Precambrian" basement relative to sea-level datum in the Albuquerque Basin . . . . . .37

TABLES

1. Geologic formations in the Albuquerque-Kirtland AFB area. . . . . . . . . . . . . . . . . . . . 12

2. Refraction geophysical experiment, CERF explosion, Kirtland AFB. 


\title{
GEOTHERMAL POTENTIAL ON KIRTLAND AIR FORCE BASE LANDS,
}

\author{
BERNALILLO COUNTY, NEW MEXICO
}

\section{INTRODUCTION}

Public policy expressed in a number of national directives in recent years emphasizes the conservation of conventional fuel supplies, a switch to alternate fuels, and the application of advanced energy technologies at federal installations. The U.S. Air Force has adopted a goal of providing one percent of installation energy from advanced energy technologies that include solar, geothermal, and wind systems by 1985. In the year 2000 the Air Force's objective is to furnish 20 percent of its installation energy requirements from these sources. Meeting these goals requires substantial activity in examining a variety of non-traditional energy technologies to select those suitable for specific sites.

Kirtland Air Force Base occupies approximately 51,000 acres $(126,021$ hectares) of contiguous lands south and east of Albuquerque. It includes joint-use of Albuquerque's International Airport; substantial office, housing, and hangar space used by the military; and a large technical complex housing the operations of Sandia National Laboratories (SNL), a U.S. Department of Energy (DOE) contractor. Only about 8 percent of the total land area, the north central part of the base adjacent to Albuquerque's city limits, has high intensity use. The rest is dedicated to specialized civilian and military research, development, and demonstration projects at sites on the base that are somewhat remote from the service and operations facilities.

The western half of the installation's total land area is a relatively flat and featureless mesa rising gradually from the Rio Grande, New Mexico's largest water artery, that flows north to south through a broad valley located some 4 to $5 \mathrm{mi}(6.4$ to $8.1 \mathrm{~km})$ west of Kirtland's western boundary. Elevations in this part are between 5,300 ft $(1,615 \mathrm{~m})$ at the western border and $5,900 \mathrm{ft}(1,800 \mathrm{~m})$ adjacent to the west slope of the Manzanita Mountains. This mountain range, sandwiched between the Sandia Mountains to the north and the Manzano Mountains south of the base, comprises the eastern 40 percent of the land area under the jurisdiction of the Air Force. The mountainous terrain consists of relatively flat and open valleys at elevations of 6,000 to $6,400 \mathrm{ft}(1,829$ to $1,950 \mathrm{~m})$ ranging to peaks that do not exceed $8,000 \mathrm{ft}(2,438 \mathrm{~m})$ in elevation.

The Albuquerque city limits bound the base to the north and northwest, Cibola National Forest and the Sandia Mountains are northeast and east, Isleta Indian Pueblo lands are adjacent to the south, and unoccupied State of New Mexico trust lands are immediately west. Entrance to Kirtland AFB and certain areas within it is restricted to authorized personnel and those on official business. The location of Kirtland AFB and its relationship to cultural, topographic, and geologic features is shown on Figure $I$ and Plate 1 . 


\section{OBJECTIVES}

Energy requirements for space heating and cooling by all entities on Kirtland $A F B$ range from a minimum load of $60,000 \mathrm{lb} / \mathrm{hr}$ of steam to a maximum of $200,000 \mathrm{lb} / \mathrm{hr}$, averaging $85,000 \mathrm{lb} / \mathrm{hr}$. Required to meet this load are $66 \times 10^{6} \mathrm{BTU} / \mathrm{hr}$ to $221 \times 10^{6} \mathrm{Btu} / \mathrm{hr}$, with an average demand of $94 \times 10^{6} \mathrm{BTU} / \mathrm{hr}$. Kirtland's energy inputs to operate their boilers are 85 to 95 percent natural gas, with No. 2 fuel oil being consumed when gas supplies are curtailed (E. R. Hoover, this report, Appendix B). Most of the equipment utilizing steam can operate satisfactorily with sceam temperatures below $340^{\circ} \mathrm{F}\left(171^{\circ} \mathrm{C}\right)$, but temperatures lower than this would require extensive modification of the existing distribution system, which would be a costly undertaking.

Studies by DOE'suggest that Kirtland's energy requirements can be met and the Air Force's objectives to obtain energy from non-petroleum sources can be realized by switching from natural gas to coal-fired' boilers. Current plans include replacing existing steam boilers on the base during the 1985-1990 period (personal communications, DOE, Albuquerque Operations Office; Plant Engineering, SNL).

A large number of recent geological, geophysical, and economic/ commercialization studies and reports describe the potential for utilizing geothermal resources in the Rio Grande Valley of New Mexico (see references). These are primarily low to intermediate temperature $\left(90^{\circ} \mathrm{F} / 32^{\circ} \mathrm{C}\right.$ to $302^{\circ} \mathrm{F} /$ $150^{\circ} \mathrm{C}$ ) hydrothermal systems identified or presumed to exist in the thick, relatively unconsolidated, geologically recent sand and gravel deposits that comprise the major groundwater aquifer throughout the length of the Rio Grande. These hot water resources could be utilized to meet a substantial part of the region's space heating requirements.

At a meeting in Albuquerque February 5, 1980, sponsored by Sandia's Geo Energy Technology Department II, 32 investigators and geothermal specialists discussed the status of regional geothermal studies and exploration programs. Subsequently, in the summer of 1980, the investigation that this report summarizes was implemented to assess the potential for utilizing geothermal resources that may exist on Kirtland AFB lands as a substitute for or supplement to the use of natural gas or coal as a primary energy input.

\section{PROCEDURES}

The summer of 1980 was spent acquiring and reviewing geological, geophysical, and hydrological data and conducting reconnaissance geological surveys. The result of much of this activity is contained in a report by Riddle and Grant (1981).

During the fall of 1980 refinement of the geology was commenced and additional surface geologic examinations were undertaken; assessment of existing literature was expanded; arrangements for coordinating a scheduled NMERI (CERF) explosion with a geophysical experiment to obtain subsurface information were made; and analysis of accumulated data was begun. Additional data useful in interpreting subsurface geologic conditions was obtained in February and March, 1981, through a gravity survey conducted on the base. The results of this activity and conclusions and recommendations derived from it are presented in this report. 


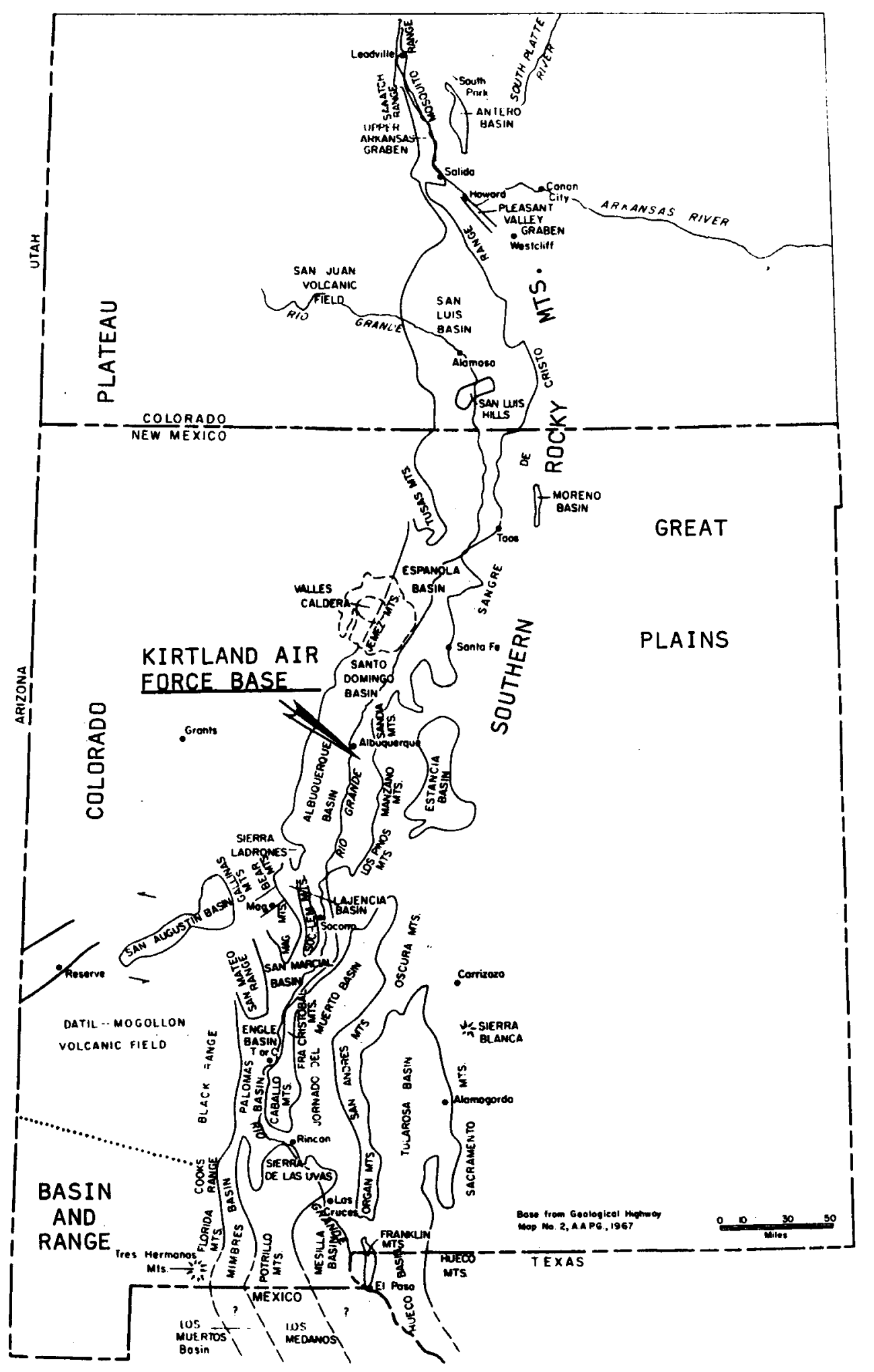

Figure 1. Location map showing relationship of Kirtland Air Force Base to geologic and geographic features of the Rio Grande Rift. Source: Chapin, 1971 . 
REGIONAL GEOLOGIC SETTING

The Albuquerque-Kirtland AFB area of central New Mexico is at the junction of four of the North American Continent's major physiographic provinces. To the west is the broad tableland of the Colorado Plateau, an uplifted region of deeply incised streams, canyons, and major volcanic centers superimposed upon a relatively underformed and stable platform. Southwest is the tectonically active and structurally deformed Basin and Range Province, characterized by severe crustal disturbances that formed numerous parallel failted mountain ranges and valleys. Immediately east, southeast, and northeast is the southernmost extension of the Continent's major structural uplift, the Rocky Mountains. Immediately east of these is the flat-lying, gradually eastward sloping, generally stable mid-continent region of the Great Plains. These relationships are shown on Figure 1 .

\section{PREVIOUS WORK}

Although located near the University of New Mexico that has a large Department of Geology granting academic degrees through the Ph.D. level, the geology of Kirtland AFB lands has not been comprehensively examined. This may be more a function of restrictions to access to these lands than any intent to disregard their scientific evaluation. Much of the base was withdrawn from public access during World War II, limiting the opportunity for more than cursory and somewhat superficial surveys.

One of the earliest references to the geology of the Albuquerque area is by C. L. Herrick (1898), then President of the University of New Mexico. His interpretation of structural and tectonic elements in the Rio Grande valley is interesting in view of later events and renewed interest in the "Rio Grande rift" by earth scientists in the past 10 or so years: "The mountains (Sandias) are part of a great monocline which extends along the left bank of the Rio Grande to the south. This monocline passes into an anticline by degrees, as the Ladrones, Limitar (sic) Mt. and Socorro range contain the same formations dipping to the west on the right bank. The Rio Grande may be said to occupy the axis of an anticline or, better still, an axis of disturbance which in various parts has resulted in different geologic structures according to the circumstances." The numerous and diverse explanations proposed by recent investigators for the development of the rift include elements of Herrick's Rio Grande anticline.

The Sandia fault on Albuquerque's east mesa, marking the west flank of the mountains, is described by Herrick and Johnson (1900) as having "cut off part of the Permo-carboniferous and superjacent strata and dropped them in various positions 4,000 feet or more..." These authors also wrote that the great expanse of lowlands occupied by the Rio Grande and the Rio Puerco to the west of Albuquerque was "a depressed area that may have formed a Tertiary sea or estuary occupying the entire width from the foot of the Sandia Mountains to the west bank of the Rio Puerco."

Bryan (1938) first identified and described the "Rio Grande depression" and its discrete, linked basins as structural elements.

Reiche (1949) has conducted the most definitive geological exploration of the Kirtland AFB region. Although primarily concerned with the structure, stratigraphy, and Precambrian geology of the Manzanita and Manzano Mountains, his limited descriptions of the structural and stratigraphic elements of the mesa comprising much of the base's land area are the most extensive in the literature. 
Beginning in the early 1950's and continuing through the present, numerous investigators have focused a great deal of attention on describing and interpreting the Rio Grande rift. Kelley (1952) was one of the first to describe the great Rio Grande depression as a rift belt with sufficient geologic status to be considered as an independent element of Rocky Mountain tectonism. Kelley and Northrop (1975), and Kelley (1977) have produced major definitive geologic treatises on the Sandia Mountains and the Albuquerque Basin. However, these and other major geological and geophysical publications on the rift relate to Kirtland AFB lands in a regional and incidental sense only.

Detailed geologic maps of the eastern part of Kirtland AFB by Myers and McKay (1970 and 1976) have been published by the United states Geological Survey (USGS). There are no published detailed geologic maps of the western part of the base. Regional geologic maps of the Albuquerque-Socorro area at a scale of $1: 250,000$ are available as open file reports of the USGS (Wyant and Olson, 1978; Machette, 1978).

\section{STRATIGRAPHY}

Rocks ranging in age from precambrian granites more than one and a half billion years old through recent wind blown sands being deposited now are present on Kirtland AFB. Table 1, Geologic Formations in the Albuquerque-Kirtland AFB Area, describes these rock units, their relative ages, and their thicknesses. Plate 1, Reconnaissance geological map of Kirtland Air Force Base and vicinity, Bernalillo and Valencia Counties, New Mexico, shows the distribution of these rock units where they are exposed on the surface.

\section{STRUCTURE}

\section{Regional Geologic History}

The development of the present landforms in north-central New Mexico is part of an unending process that began hundreds of millions of years ago. The record of mountains and uplifts that precedes the ones we see today as well as the processes that deposited the varied types of rocks throughout the region is established by observation and investigation.

Analysis of the earth's history by interpreting the sequence of geologic events and the timing of significant episodes, together with the use of data obtained from deep wells and application of geophysical techniques, is crucial in order to arrive at conclusions that may be economically important in geothermal and other resource investigations.

Because Precambrian rocks are exposed only in the major nearby uplifts in the Sandia and Manzano Mountains, little is known about structural conditions when they were formed.

The record becomes better established during Paleozoic time. No rocks older than Mississippian are preserved in the region, indicating that this part of the state was above sea level during periods when older rocks, present in southern New Mexico, were being deposited. If marine (ocean) conditions did exist in north central New Mexico during Cambrian, Ordovician, Silurian or Devonian time, the record of their rock deposits was removed by erosion before the thin marine shelf units of 
Table 1. Geologic Formations in the Albuquerque-Kirtland AFB Area (Adapted from Kelley, 1974)

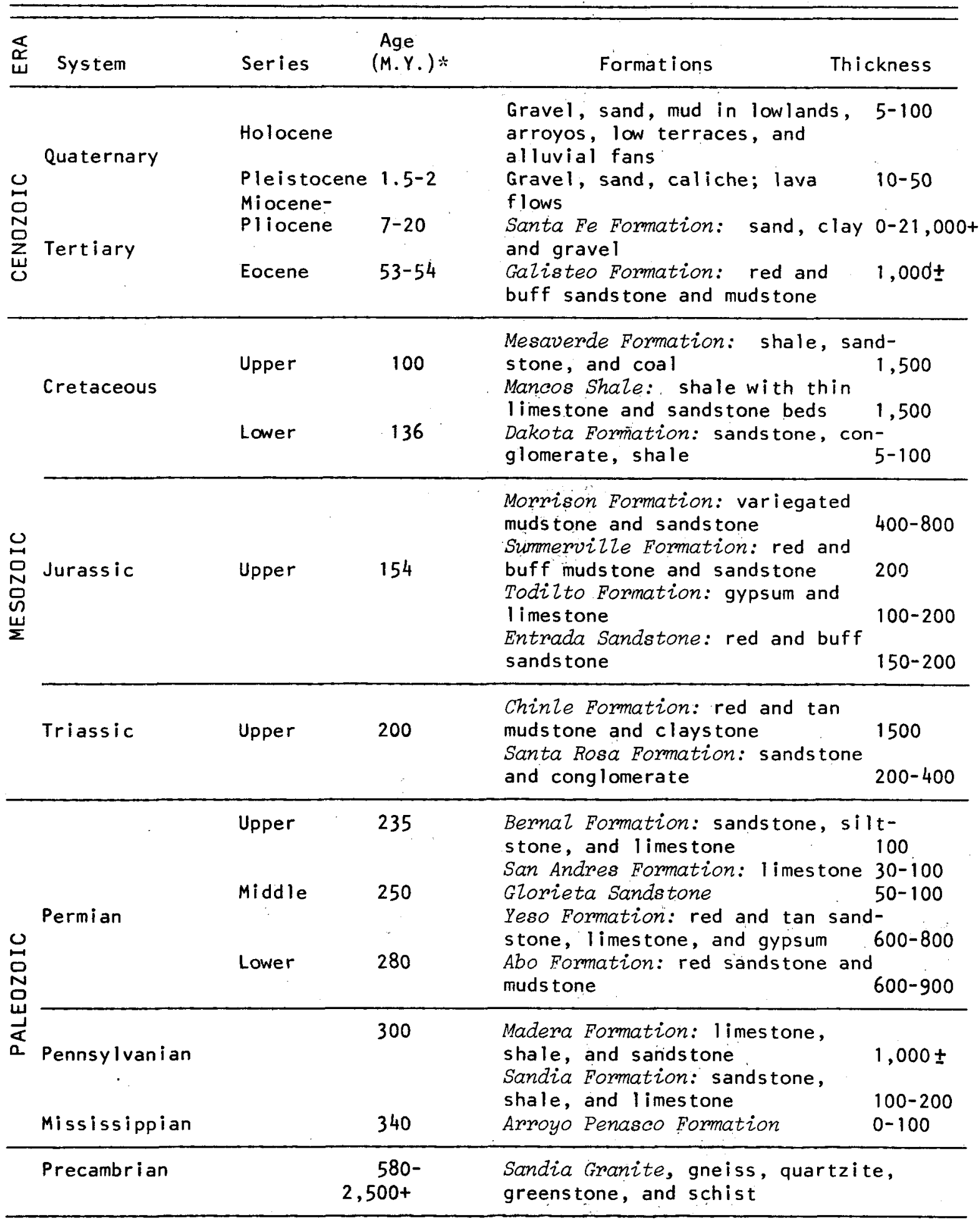

$* M . Y .=$ millions of years from the beginning of the system or series. 
Mississippian age were deposited over most of the area. It is probable that the region was a broad, gently southwest sloping positive (above sea level) land mass during earliest Paleozoic time.

In late Pennsylvanian and early Permian time a series of large, extensive basins and mountain uplifts of regional extent were formed in northern New Mexico and Colorado. Geologists refer to these structures as the Ancestral Rockies because, in many places, they correspond to our present mountain uplifts. This period of major orogeny (mountain building) may have established structural zones and elements that have become the focus for subsequent tectonic (deformation of the earth's crust) events. The uplifts and basins that were created at this time covered a large part of northern New Mexico and generally established landforms that trended north-northwest into colorado and utah.

Marine conditions evidenced by the thick accumulations of Pennsylvanian (Madera) limestones were superseded by a flood of clastic material being eroded from major highlands during early Permian. The continental Abo Formation was deposited on the surface of limestones left by the retreating Pennsylvanian sea, while the Yeso, Glorieta, San Andres, and Bernal Formations were deposited successively on the Abo floodplain in arid back-reef seaways, restricted lagoons or marginal shorelines. The Abo beds are fluvial (distributed by river systems) subaerial (land) deposits whereas the later formations are evaporitic, marine, and in part littoral (near-shoreline) and eolian (wind blown) in origin.

By late Permian time the region had become a relatively stable, probably unimpressive positive area of low relief shedding few sediments to be preserved in the record.

Warm, wet and humid conditions again returned to the area in late Triassic time, as well as renewed uplift to the north to establish major streams and floodplains. Muds (shale), sands and gravel (conglomerate) were accumulated in great thicknesses over much of the area, represented by the Chinle Formation.

The record was once again interrupted in early and middle Jurassic time by cessation of deposition due to very stable continental conditions. The next environment the rocks suggest must have been an extremely inhospitable one; very dry and windy, possibly somewhat like the Sahara Desert today. The Entrada Sandstone represents these conditions with clean, wind blown dune sands preserved in the section. Conditions changed with invasion of a widespread lake entering the region from the west to dominate central New Mexico for a geologically brief period. When arid conditions returned, the lake dried up leaving accumulations of white gypsum and limestone that are preserved in the Todilto Formation.

A slow, persistent subsidence began in Morrison time in which muds, sands and gravels were spread in extensive floodplains by rivers, lake currents, and winds originating in south-central colorado into a broad, shallow depression. This environment was conducive to establishment of a flourishing ecology of land animals (the dinosaurs that became established during Triassic time) and plants that was one of the greatest periods of faunal development in the earth's history.

After a prolonged period of relative stability, the entire western part of the United States began subsiding and a major invasion of Cretaceous seas that moved west and southwest across the pre-existing Jurassic landscape begin. The initial deposit was a sheet-like marine beach or near-shore sandstone, the Dakota Formation, which was buried 
and preserved beneath thick accumulations of the black, marine Mancos Formation shales. Uplifts in southwestern New Mexico in late Cretaceous time "pushed" the cretaceous ocean back to the northeast. Swamp conditions that developed behind the shoreline are responsible for the accumulation of large amounts of carbonaceous material in the Menefee portion of the Mesa Verde Formation, which contains most of New Mexico's vast coal reserves.

Near the end of Cretaceous time and continuing into late Eocene a major tectonic event, the Laramide orogeny, produced the first generation of present day Rocky Mountains and their adjoining basins. Uplift of the southern Sangre de Cristo and Sandia Mountains probably occurred during this period, stripping away the cretaceous rocks that had been deposited over them. The Nacimiento Mountains on the east side of the San Juan Basin began to develop through high angle reverse faulting along their western flank during very late Cretaceous and were rejuvenated again in early Eocene. By the end of Eocene, most of these mountain ranges had been eroded back down to the level of surrounding plains. The topographic relief of the entire region was low and a shallow structural basin was formed that extended from northwest of present day Espanola south to the vicinity of Cerrillos and Galisteo and southwest to near San Ysidro that filled with sediments of the Galisteo Formation.

In Oligocene and Miocene time large scale volcanism began in the vicinity of the Ortiz and San Pedro Mountains near Cerrillos and some minor activity commenced where the present Jemez Mountains are. Rocks previously deposited were tilted up at an angle to be overlain by later sediments in many areas where present mountain ranges began to be compressed upward again.

About 20 million years ago, during the Miocene, basins began to form in which sediments of the Tesuque Formation and the Santa Fe Group were deposited. This basin was larger, broader and more shallow than the present intermontane basins between the Lucero Uplift and the Nacimientos on the west and the Manzanos, Sandias, and Sangre de Cristos on the east.

The present structural basins of the large Rio Grande depression in north central New Mexico began to form in late Miocene-early Pliocene, about 5 to 10 million years ago. Major faults or fault zones bound the basins next to the mountain uplifts. Ultimately, these breaks in the earth's crust moved the same rock horizons up or down relative to each other more than $30,000 \mathrm{ft}(9,144 \mathrm{~m})$ between rocks buried beneath the Rio Grande at Albuquerque and those exposed on the top of the Sandia Mountains.

Throughout its most recent development the terrain in the Albuquerque region was probably similar to what we see now, except the relief was not as great in the mountain areas. Broad valley floors, alluvial fans, pediment surfaces, terraces, rivers, lakes, fault scarps, and active volcanoes were part of the scenery. Many of these features were buried beneath new waves of sediments to add to the complexity of determining the region's history.

\section{Subsurface Relationships}

Geologic information about the rocks below the present land surface is sparse in this region. Where they are not exposed, inferences are made as to the kinds of rocks, their occurrence, composition, attitude, relation to other rocks, thickness, and depth from the surface on the basis of nearby outcrops, surface observations, well cuttings and mechanical $\log s$, and geophysical information. 
Shell oil Company initiated an exploration drilling program for hydrocarbons in the Albuquerque Basin in 1972. Of approximately 12 deep tests drilled in the Albuquerque Basin within about $30 \mathrm{mi}(48 \mathrm{~km})$ of Kirtland $A F B$, shell has been responsible for 7 wells ranging in depth from 10,276 to $21,266 \mathrm{ft}(3,132$ to $6,482 \mathrm{~km})$. The location of several of the nearest wells is shown on Plate 1 and Figure 7 .

Regional geophysical data incorporating gravity mapping and interpretation has been published by the USGS and others. Of particular interest is a Complete Bouger Gravity Anomaly Map of the Rio Grande Rift by Cordell and others (1978), and a Residual Bouger Gravity Anomaly Map of New Mexico by Aiken and others (1978). Cordell (1978a, 1978b, 1979) and Birch (1980) have made substantial contributions to the interpretation of structural conditions within the Albuquerque Basin as well as its sedimentary history.

\section{Earthquakes}

Earthquakes are the shock waves felt on the land's surface as a result of movement produced by the sudden displacement of rocks on or below the earth's surface. They are constant, ongoing features of the developmental processes of the earth.

Because of the large number of faults in the tectonically active Rio Grande region, many of them formed geologically recently in connection with development of the basins of the Rio Grande and volcanism in the Jemez Mountains, the area has been considered a relatively high seismic (earthquake) risk area.

Detailed instrumental measurements of earthquake activity began in New Mexico in 1960. Information about previous earthquakes comes mainly from historical records. Northrop (1976) has studied New Mexico's earthquakes for some time and his conclusions are of interest. Historical records show that New Mexico has had at least 1,111 earthquakes in the 127-year period 1849-1976. Seventy-six percent of these occurred in the 75 mile segment between Socorro and Albuquerque. Statistically, an earthquake can be expected every 3 years in the Socorro-Albuquerque area. One of sufficient intensity to do considerable damage should be expected once every 100 years. The latest New Mexico earthquakes of this magnitude occurred at socorro in 1906, Cerrillos in 1918, Silver City in 1938, and Dulce in 1966.

As a result of concern about seismic risk, Los Alamos National Laboratory (LANL) established a network of seismic stations in north central New Mexico in 1972. Preliminary data (Newton and others, 1976) on contemporary tectonic activity near the Valles Caldera and the Rio Grande rift shows concentrations of minor earthquakes 1) along the Nacimiento Uplift and its northward extension to Dulce; 2) near Abiquiu, north of Los Alamos and Espanola; 3) beneath the western part of the Taos plateau; and 4) within the Rio Puerco fault zone between Albuquerque and Grants. Almost no earthquakes are originating beneath the Valles Caldera of the Jemez Mountains (site of LANL's Hot Dry Rock geothermal program and the joint venture of Union Geothermal Company, Public Service Company of New Mexico, and DOE to develop the country's first commercial hot water electrical generating system), suggesting the presence of a hot, shallow, not necessarily molten body where strain relief occurs by creep rather than by brittle fracture. The instrumental and historical seismicity and earthquake evidence from fault displacements consistently show the overall region to have moderate activity. 


\section{Volcanism}

New Mexico is the center of a significant amount of volcanic activity, some of which occurred as recently as 1,000 years ago when the Carrizozo lava flow issued from a vent northwest of the community. The malpais east and south of Grants is dated about 700 A.D. Capulin peak, in northeastern New Mexico is less than 8,000 years old. Lava west of Los Lunas and Isleta spilled out about 140,000 years ago and the volcanoes on Albuquerque's west mesa were erupting less than 200,000 years ago (Luedke and Smith, 1978).

The Jemez Mountain volcanic pile has been developing over the past 10.5 million years. Radiometric age dating methods suggest that the last eruption in the Valles Caldera happened about 42,000 years ago (Bailey and Smith, 1978). Smith, Bailey and Russell (1978) indicate that repose (inactive) periods for this volcano longer than a few hundred thousand years are doubtful and, in the light of the total record, the Jemez field has high potential for future eruptions.

\section{THE RIO GRANDE RIFT}

The Rio Grande from its headwaters in the western San Luis Valley of south central Colorado to the vicinity of El Paso flows through a great depression that, in general, it did not erode. In its course the river flows through a series of en-echelon troughs or grabens that have subsided between mountain uplifts. It is believed by a large number of investigators that the earth's crust has pulled part in this region and the Rio Grande has occupied itself for millions of years with filling these foundered elements with the clays, sands, and gravels (valley fill) eroded from adjacent uplifts, together with much of the water the river used to transport this huge sediment load (Kelley, 1974).

Other concepts have been proposed for the formation of the Rift that involve assumptions of continental drift, compression through plate collision, and collapse of a regional arch. Baltz (1978) effectively summarizes divergent viewpoints for the origin of the Rio Grande rift:

"Interpretations of the origin of the Rio Grande rift seem to depend partly on one's view of what constitutes the rift. If the rift is viewed as relatively discrete (that is, viewed as comprising the basins of the Rio Grande depression); one might believe that its position and origin were predestined because of an ancient deep crustal discontinuity, a crustal spreading center, or an evolutionary consequence of a subduction zone. All of these ideas have been postulated recently.

"On the other hand, one might envision the rift as a regionally broad and pervasive 'system' of Neogene faults, such as the Rio Grande rift system of Tweto (1977) in Colorado and the rift in southern New Mexico as portrayed by Chapin and Seager (1975), and Woodward and others (1975). In this case, one might interpret the rift as the eastern vagaries of slight intraplate shifting, or stretching because of vertical crustal movements, and of shattering of large areas during regionally varying amounts of the Neogene epeirogenic uplift of a large region of the southwestern United States. Such an impression is heightened because basalts of late Miocene, Pliocene, and Pleistocene 
ages were erupted not only in the Rio Grande depression,

but also in the Colorado Plateau and Great Plains outside the area considered to be the Rio Grande rift."

The "last" words produced on the subject of the tectonic events that formed the Rio Grande rift are by Chapin (1979). He theorizes that the total extension or spreading in the rift must be on the order of 100-1508 to accommodate the volumes of basaltic magma injected into the crust to support heat flow anomalies and "to explain the residual positive gravity anomaly along the rift axis." He also suggests that rifting is continuing today "as evidenced by abundant fault scarps cutting Pleistocene deposits, high heat flow, modern elevation changes, modern magma bodies, and geophysical evidence for anomalous crust and upper mantle beneath the rift." Note that these constructions include substantial elements of geothermal systems.

\section{ALBUQUERQUE BASIN}

The Albuquerque Basin is a large, complex tectonic element of about 4,300 sq $\mathrm{mi}$ that extends from near the junction of the Rio salado close to San Acacia on the south, to the La Bajada escarpment and White Rock gorge of the Rio Grande on the north. Generally, the northern part of the basin is presumed to be an east-tilted fault block that is distorted by faulting and compression. The western margin of the basin is the Rio Puerco fault zone. Slack and Campbell (1976) indicate that this region is broken by en-echelon faulting downthrown both east and west. Individual faults may have displacements of about 3,200 ft (l km). The eastern boundary of the basin appears to be marked by large faults near the base of the Sandia Mountains to the north and a fault or faults west of a bedrock bench extending 4 to $6 \mathrm{mi}(6.5$ to $10 \mathrm{~km})$ west of the Manzano and Los Pinos Mountains to the south. The basin is about $102 \mathrm{mi}$ $(164 \mathrm{~km})$ long and 25 to $40 \mathrm{mi}(40$ to $65 \mathrm{~km})$ wide. The ends of the basin are open through narrow bedrock constrictions to the San Marcial (Socorro) Basin to the south and the Espanola Basin to the north. According to Baltz (1978), the northern boundary of the Albuquerque Basin is concealed by the Jemez Mountains volcanic pile. Figure 2 shows the Albuquerque Basin and its relationship to other major tectonic features in central New Mexico.

Indicative of the basin's structural complexity, the shell oil Company No. 2 Isleta exploratory well, drilled in section $16, \mathrm{~T} 8 \mathrm{~N}$, $R 2 \mathrm{E}$, was completed in 1980 at a depth of $21,266 \mathrm{ft}(6,482 \mathrm{~m})$ in what was reported to be valley fill. Six miles east in section $8, T$, 8 , R $3 \mathrm{E}$, the Trans Ocean No. 1 Isleta penetrated $5,250 \mathrm{ft}(1,600 \mathrm{~m})$ of valley fill before encountering Cretaceous rocks. At $10,324 \mathrm{ft}(3,147 \mathrm{~m})$ Precambrian was encountered in the Trans Ocean well. Assuming that the Shell well bottomed close to the top of the Cretaceous, adding 5,000 ft $(1,524 \mathrm{~m})$ of sedimentary rocks overlying the Precambrian to its $21,266 \mathrm{ft}$ $(6,482 \mathrm{~m})$ depth would suggest that the Precambrian would be encountered at not less than $26,266 \mathrm{ft}(8,006 \mathrm{~m})$, or $21,135 \mathrm{ft}(6,442 \mathrm{~m})$ below sea level (surface elevation of $5,131 \mathrm{ft} / 1,564 \mathrm{~m}$ less drilling depth to Precambrian). The similar datum at the Trans Ocean well was $5,114 \mathrm{ft}$ $(1,557 \mathrm{~m})$ below sea level, indicating a minimum of $16,021 \mathrm{ft}(4,883 \mathrm{~m})$ displacement of subsurface relief between the top of the Precambrian in the two wells. Further, the same relationship between similar horizons is found at an elevation of more than $10,000 \mathrm{ft}(3,048 \mathrm{~m})$ above sea level at the top of the Sandia Mountains. The stratigraphic displacement is at least $31,135 \mathrm{ft}(9,490 \mathrm{~m})$ or almost $6 \mathrm{mi}(9.7 \mathrm{~km})$ between the Shell well and the highest point of the sandias. 


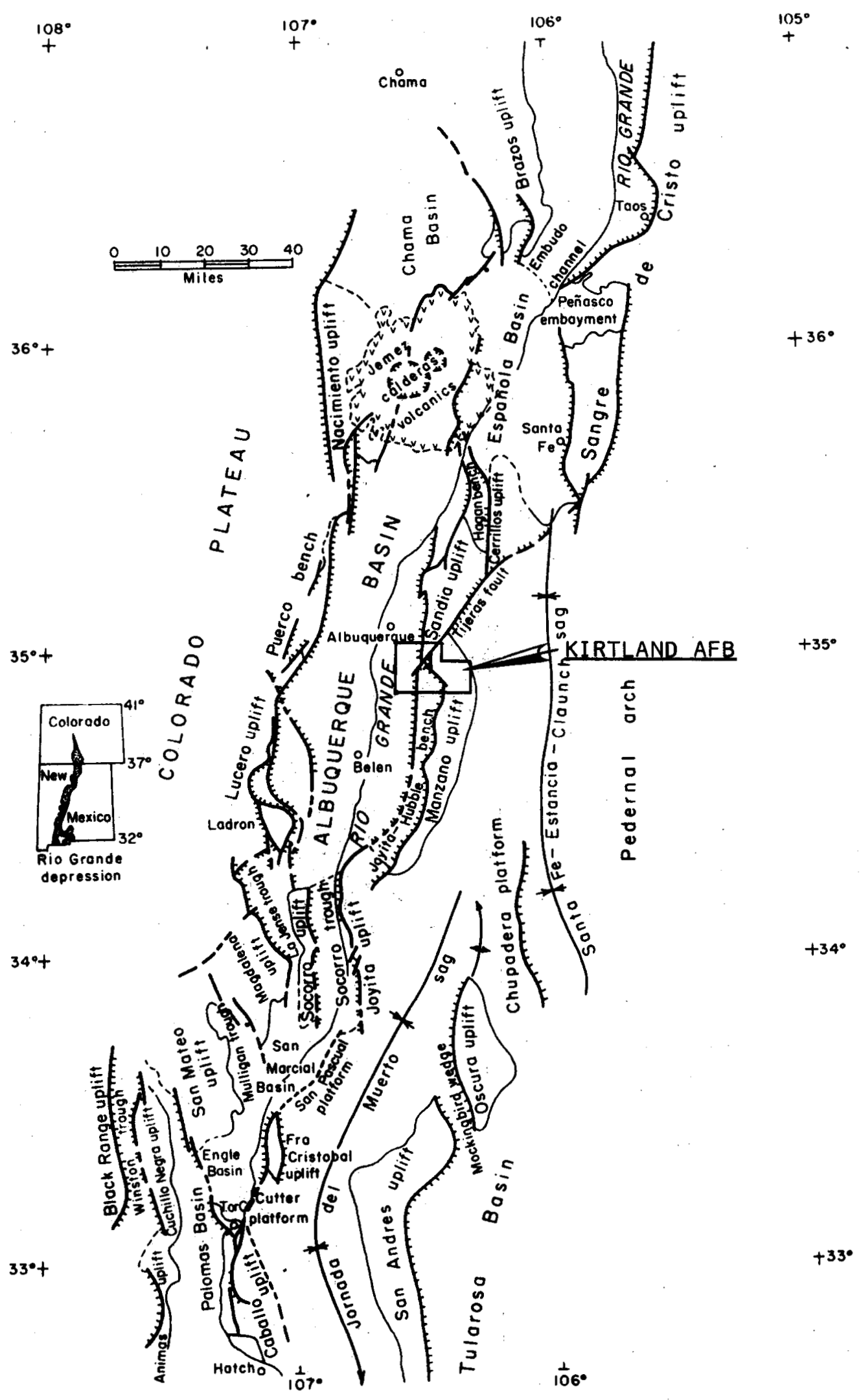

Figure 2. Tectonic map of the Rio Grande Rift System in New Mexico (Kelley, 1977). 
Kelley (1977) offers an excellent summary of the geology of the eastern part of the Albuquerque Basin, including Kirtland AFB lands:

"Perhaps the most important concept developed in this study has been the postulating of structural benches and steps within the basin. Most important of these is the Joyita-Hubbell bench. Downthrow on its west side faults could be as great or greater than downthrow of the bench with reference to the prominent uplifts to the east. In other words the bench edge zone could be the principal eastern structural boundary of the Rio Grande trough from well into the Socorro constriction on the south to the Tijeras fault and the Sandia uplift on the north. This may be especially true when it is realized that 65-70 percent of the western relief of the Manzano uplift is not trough relief but rather is relic from the Laramide and that the structural relief of the Manzanita Plateau above the Hubbell part of the bench is hardly 1,000 feet. The Hubbell springs fault scarp of possible early Holocene is the principal means by which the fault is identified. If it were not for the late movement, the existence of the old fault would be unknown. Furthermore, there may be parallel buried faults west of the Hubbell springs scarp forming into an axial trough. Based on only the scarp, throw on the fault would be no more than 150 feet. If this is the total displacement on the fault, then the Triassic and Permian exposed in the scarp would be no more than 50 feet or so beneath the surface on the downthrown side. This possibility needs to be determined by drilling or by some other way. More likely, however, is that the Hubbell springs scarp displacement is merely renewed late movement on an older fault of great displacements. The marked gravity inflection which parallels the fault is strong support for a growth fault. If one grants the growth fault character of the Hubbell springs fault and its possible magnitude, then the next question is whether it pre-dates or post-dates the frontal faults of the uplift. Absence of Santa $\mathrm{Fe}$ beds in thicknesses of more than a few tens of feet is perhaps the best evidence that the Manzano-Los Pinos faults are younger and that only the Laramide Mountains existed when the Hubbell springs and Joyita fault began to drop the central part of the Rio Grande trough. If the major displacement of the Hubbell springs fault were later than the back bench or uplift frontal faults, it should have more physiographic expression than it does, and the Triassic and Permian rocks, which surface the fault now, might have been more likely stripped prior to a later dropping of the bench.

"Although the Los Pinos to Sandia line of uplift bordering the basin has a degree of geomorphic oneness, there is considerable difference in structure and possibly origin, especially north and south of the Tijeras fault and fold zone. South of the fault the Manzanita to Los Pinos section is tilted very little whereas to the north the Sandia section is markedly tilted. Furthermore, the Sandia front stands 2-6 miles westward of the straight Manzano-Manzanita front. Sandia uplift has no known structural bench, yet its frontal fault is roughly on line and perhaps to a degree continuous with the Hubbell springs fault. Sandia 
uplift may not have experienced its principal uplift until

late Santa Fe time as explained by Kelley and Northrop (1975).

The Sandia block may have been a bench in the beginning

from the point of view of basin tectonics. At such time the

back of the bench may have been defined by a fault zone that

extended from the Tijeras to La Bajada faults. The Sandia

with its great structural relief and youthful escarpments

may have had early structural continuity in both space and time with the postulated early Hubbell springs fault and again later in time with the Manzano-Los Pinos faulting. The youthfulness of the Sandia is well illustrated by fan, terrace, and pediment scarps and by its fresh triangular fault-scarp facets. Perhaps also related to the late rise of the Sandia block is the expansive eastward inclination of the Santa Fe formations across the basin which coincides in latitude with the Sandia block.

"In summary, the east side of the trough originated by repeated downthrow often on the same principal faults. Apparently the trough was narrower in the beginning. Most of the outer faults marking the prominent uplift came later and widened the basin. An exception may be the Sandia fault, which might have been a bench fault early and an uplift fault later."

\section{KIRTLAND AIR FORCE BASE}

\section{Physiographic Provinces}

Virtually all of the principal tectonic events that formed the east side of the Rio Grande rift, the Albuquerque Basin, and the adjoining mountain ranges occurred on and have profoundly affected Kirtland AFB lands. At least two major faults, the Tijeras fault with movement commencing in the Precambrian and continuing through the present, and the Hubbell springs fault, believed to be the geologically recent fracture that marks the east side of the rift, intersect on the base. Two other faults or fault systems, the Manzano fault that raised the Manzanita and Manzano Mountains $1,300 \mathrm{ft}$ to $3,000 \mathrm{ft}$ (396 m to $914 \mathrm{~m}$ ) above the Hubbell bench, and the Sandia fault that may be a northward extension of the Hubbell springs fault and is presumed to have been the point where the massive, east-tilted Sandia Mountains broke away from rocks underlying the Rio Grande rift, complete the gross tectonic setting.

These faults are the geologic basis for subdividing the base into four distinct physiographic provinces. The wedge-shaped triangle formed by the southwestward projecting Four Hills Precambrian granite outcrops, terminating at the travertine outcrops in the south half of section 28 and north half of section 33, T $9 \mathrm{~N}, \mathrm{R} 4 \mathrm{E}$, is the southernmost extension of the Sandia Mountains. East of the Manzano fault on the base are the Manzanita Mountains, a relatively undeformed uplift exposing Precambrian rocks capped by flat-lying Pennsylvanian limestones. South of the Tijeras fault, west of the Manzano fault, and east of the Hubbell Springs fault is the Hubbell Bench province, a zone of Permian, Pennsylvanian, and Precambrian rock's mostly capped by a thin veneer of alluvium. The Permian rocks are exposed at Hubbell Springs on the Isleta Indian Reservation, about one mile south of the base. The Pennsylvanian and some Precambrian exposures are on both sides of coyote creek from its mouth to the point where it crosses the Tijeras fault and the south 
end of the Four Hills (Sandia) uplift. These rocks exhibit a great deal of folding and faulting incidental to vertical and horizontal movement on the nearby Tijeras fault. West of the Hubbell springs and Sandia faults is the Albuquerque Basin, the only one of the four provinces with significant geothermal implications. These relationships are shown on Plate 1 and Figure 3 .

\section{Tijeras Fault}

The Tijeras fault and related tectonic system is one of the most extensive in New Mexico. It is readily identified in surface exposures from its intersection and probable point of severing by the later Hubbell springs fault on the base, extending northeastward about $58 \mathrm{mi}$ $(93 \mathrm{~km})$ to the Canoncito area of the Sangre de Cristo Mountains about $14 \mathrm{mi}(9 \mathrm{~km})$ southeast of Santa $\mathrm{Fe}$. It is probable that the fault extended southwest across the area presently occupied by the Albuquerque Basin prior to rifting (Ander, 1980; Cordell, 1976). If so, it was. bisected by the Hubbell Springs fault and dropped or collapsed with its related segments into the rift, complicating the geometry of structural details in the Albuquerque Basin beneath Kirtland AFB.

Lisenbee and others (1979) state that the fault has undergone recurrent movement since Precambrian time, it cuts rocks ranging in age from Precambrian to late Tertiary, and on the southwestern (Kirtland AFB) end had lateral or horizontal movement of several $\mathrm{mi}(\mathrm{km})$ of left slip. These authors identified an area in Tijeras Canyon in a roadcut where Precambrian greenstone is in fault contact with colluvium of probable Quaternary age. They suggest that this recent offset and historic earthquake activity indicate that future movement along the Tijeras fault in this area is likely.

Reiche (1949) mapped the Tijeras fault and indicated that it dipped steeply, its downthrown side was to the east, and brought the sandia granite into contact with Precambrian quartzites, Pennsylvanian limestones, and upper Tertiary sands and gravels at its southernmost point. Reiche did not measure its displacement but presumed it was measured in thousands of feet.

Chapin and others (1978) have mapped several major crustal lineaments trending northeast across New Mexico and Colorado. These shear zones dominate the structural grain of Precambrian rocks in the southern Rocky Mountains, tend to be oriented along lines of Laramide volcanic plutons as well as recent lava flows of predominantly basaltic composition, and generally coincide with well known mineral belts. Where these lineaments cross the Rio Grande rift they produce a characteristic suite of structural elements where, among other complex features, high heat flow and geothermal activity are not uncommon. Although not included in the lineaments described by these investigators, the Tijeras fault system would appear to have similar qualities in terms of age, trend, displacement, mineralization (Tijeras Canyon, San Pedro, ortiz, and by extension, Pecos mining districts), volcanism (Cerro Verde, Lucero Mesa, Cat Hills, Wind Mesa, and Isleta volcanic centers just west of the Rio Grande), and apparent basement complexity.

Hubbell springs Fault

The Hubbell springs fault is a remarkable geologic feature. Its length is apparently unbroken for about $36 \mathrm{mi}(58 \mathrm{~km})$ from the southeast part of $T 3 \mathrm{~N}, \mathrm{R} 4 \mathrm{E}$, to its intersection on the base with the Tijeras fault. If the presumed sandia fault is an extension of it, its length would be some $22 \mathrm{mi}(35 \mathrm{~km})$ longer. It has almost perfect straight 


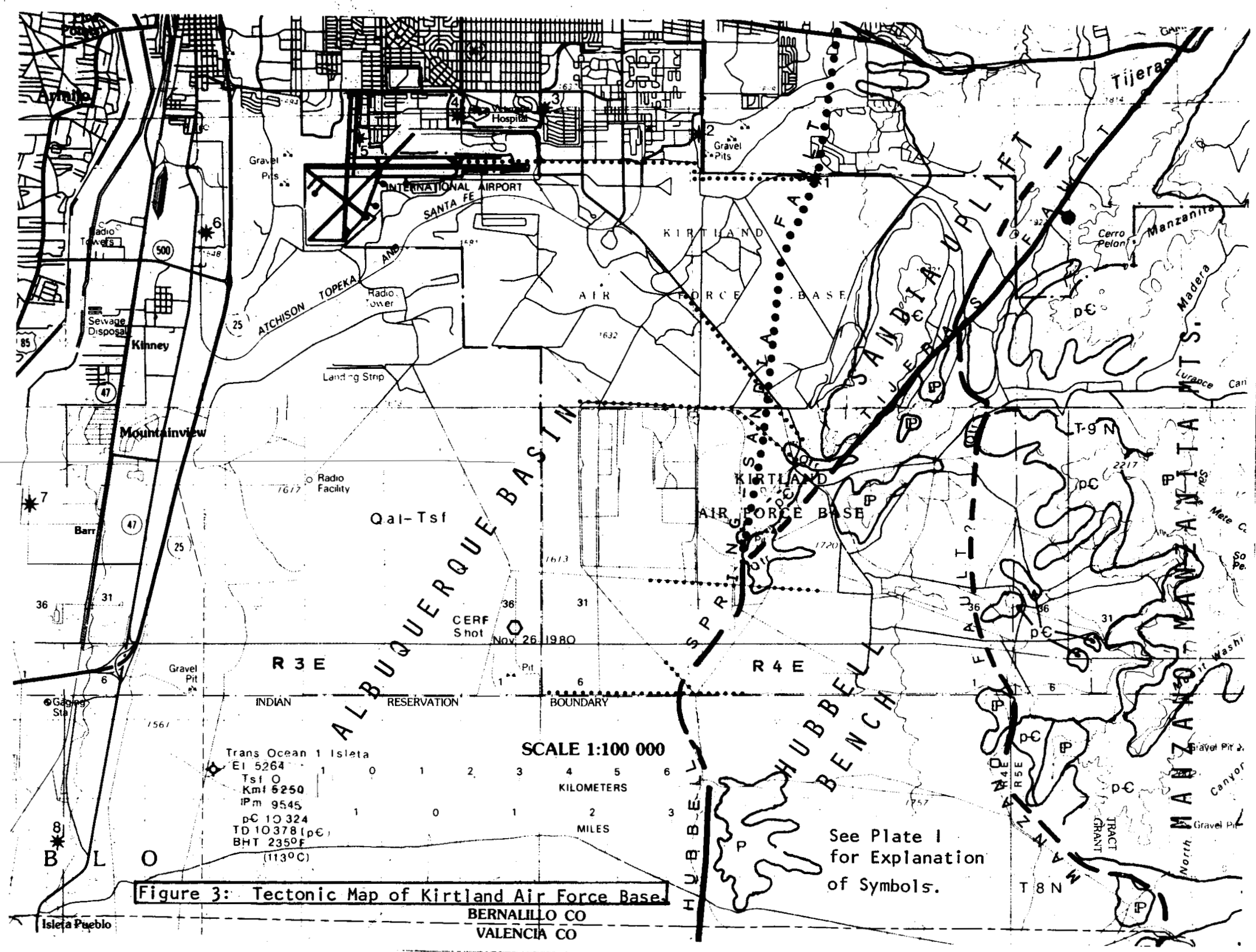


line symmetry from south to north and it aligned with a series of fresh water springs in the northern $18 \mathrm{mi}(29 \mathrm{~km})$ of its length. These springs, Ojo Huelos, Carrizo, Maes, Ojo de la Cabra, and Hubbell springs, are located on an otherwise barren, arid mesa some 4 to $6 \mathrm{mi}$ ( 6 to $10 \mathrm{~km}$ ) east of the Manzano Mountain front, easily identified by large cottonwood trees (the only trees on the east mesa). Recent movement has raised a prominent scarp along its northern length on the east side of the fault. The scarp rises 100 to $150 \mathrm{ft}(30$ to $46 \mathrm{~m})$, is sharply defined, is incised by east-west arroyos, and supports an apparent homogeneous block of flat lying sediments of Triassic through Pennsylvanian age overlying Precambrian rocks. These sediments are exposed in the vicinity of ojo Huelos, Hubbell springs, and the Tijeras fault and appear to be covered by a thin veneer of alluvium and fan material elsewhere.

Titus (1963) has an excellent description of the fault, its identification, and relationship to the groundwater regime which is important to the geothermal model on Kirtland AFB:

"Ground water moves westward from the Manzano Mountains toward the Rio Grande in the Cenzoic sediments which rest on rocks of Permian and Triassic age in the upthrown block of the ojuelos (Hubbell springs) fault. Ground water also is presumed to move westward toward the fault through permeable beds of the older underlying rocks. East of the Ojuelos (Hubbell Springs) fault the water table in much of the area is less than 100 feet below land surface; at the fault the several springs indicate that the water table is at the surface; west of the fault the water table is 400 to 500 feet below the surface. As water moves across the fault into the more permeable rocks of the Santa $\mathrm{Fe}$, it cascades abruptly to the lower level within a short distance. The slope of the water table east of the fault is between 100 and 200 feet a mile. West of the fault, beyond the zone of cascading ground water, the water-table slope in most places is less than 10 feet a mile. Although the ojuelos (Hubbell springs) fault does not have a topographic expression that is recognizable in the southern part of valencia County, the location of the ground-water cascade over the fault can be determined within four or five miles by the configuration of the water table."

Whether the Hubbell springs fault is a master fault identifying the east side of the Rio Grande rift or one of several step faults that control basement topography is presently unknown. Unlike the surface geology that can be mapped without great difficulty throughout the base and adjoining areas, subsurface structural and stratigraphic relationships appear to be complex and subject to various interpretations.

Cordell (1976), Cordell and others (1978), and Aiken and others (1978) have prepared gravity maps of the region that strongly suggest that the Hubbell springs fault is a steeply dipping fracture. Cordell (1979) interprets the gravity data to mean that the regional (Rio Grande rift) fault system may comprise a relatively small number of large, widely spaced, high angle (at shallow levels) master faults that may be identified by long, linear, large amplitude gravity gradients. Birch (1980) has attempted to determine the subsurface geology of the Albuquerque-Belen basin by analysis and interpretation of gravity anomalies on the published maps of Cordell and others (1978). His gravity profiles (cross sections) west to east across the rift indicate that the Hubbell springs fault is a single element, steeply dipping into the basin. Figure 4 is Cordell's 1976 gravity map of central New Mexico showing the geophysical complexities of the Albuquerque Basin. 


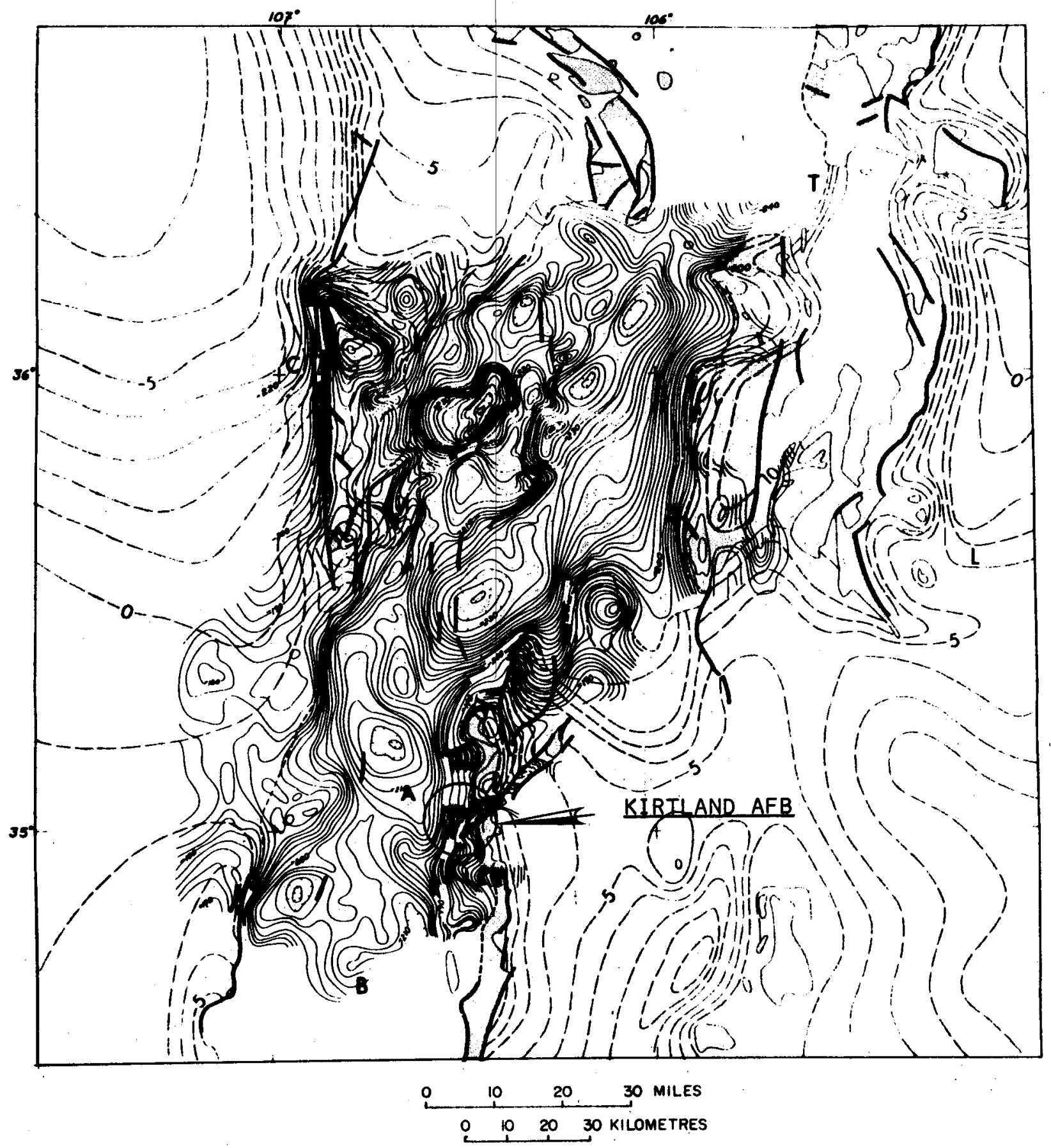

Figure 4. Preliminary Complete Bouguer Anomaly gravity map of part of the Rio Grande rift in northcentral New Mexico. Countour interval: 2 mgals. A: Albuquerque; B: Belin; C: Cuba; L: Las Vegas; S: Santa $\mathrm{Fe} ; \mathrm{T}$ : Taos. (Source: Cordell, 1976.) 
Parker (this report, Appendix A), conducted a gravity survey on the base that featured a sharp break in the gravity slope crossing the South Fence road at the north boundary of the Isleta Indian Reservation, in the east half of section 5, T $8 \mathrm{~N}, \mathrm{R} 4 \mathrm{E}$. An east-west traverse on Magazine road encountered the same subsurface feature about in the center of the north half of section $33, \mathrm{~T} 9 \mathrm{~N}, \mathrm{R} 4 \mathrm{E}$, about $3,800 \mathrm{ft}(1,158 \mathrm{~m})$, west of the west entrance to the solar power tower. It is believed that these are traces of the Hubbell springs fault.

"Sandia Fault"

Kelley (1977), Kelley and Northrop (1975), and Woodward and others (1975) postulate a major rift fault separating the Sandia Mountain uplift from the Albuquerque Basin that extends from the southwest extension of the Four Hills uplift on the base northward to the placitas area of Sandoval County, a north-south distance of about $25 \mathrm{mi}(40 \mathrm{~km})$. This fracture may be called the sandia fault and, according to kelley and. Northrop (1975) its surface trace can be seen in only three places. To the south a fault is exposed at the mouth of Tijeras canyon on the east side of the road leading into the Four Hills subdivision in approximately the center of the west half of section $26, T 10 \mathrm{~N}, \mathrm{R} 5 \mathrm{E}$. Another exposure is a minor scarp located by Kelley at the base of the Rincon spur of the Sandia Mountains on the Sandia Indian Reservation. The third outcrop is apparently where the fault crosses NM-44 near the northern end of the Sandias in section $1, T 12 \mathrm{~N}, \mathrm{R} 4 \mathrm{E}$. Other evidence for the Sandia fault is found in the gravity maps of Cordell and others (1978) and Aiken and others (1978). Cordell (1978b) described a buried fault on the steep, linear gravity gradient taken from a detailed profile along Tramway road between I-25 and the Juan Tabo picnic area (approximately the southwest corner of section $3, T 11 \mathrm{~N}, \mathrm{R} 4 \mathrm{E}$ ) as being a single large, steep fault with structural relief of at least 3,000 to $6,000 \mathrm{ft}$ ( 1 to $2 \mathrm{~km}$ ).

Evidence for this fault bounding the west side of the Four Hills uplift part of the Sandia Mountains on Kirtland AFB is somewhat subjective. Geologically, a major fault should be present here in order to account for the enormous structural relief between the deepest parts of the rift identified by well data and the top of the sandias, apparently more than $30,000 \mathrm{ft}(9,144 \mathrm{~m})$.

Reiche (1949) mapped a fault on the surface extending southwest through the north central part of section 22 to the center of section 28 , T $9 \mathrm{~N}, \mathrm{R} 4 \mathrm{E}$. He describes a small alluvial fan built by coyote arroyo at this location as being offset vertically about $25 \mathrm{ft}(8 \mathrm{~m})$ and, "Although the scarplet is battered, the evidence is definite; it includes small fissure fillings of travertine due to a former artesian spring." Field investigation failed to locate the scarp Reiche describes, but travertine is present, and the location has been subjected to considerable earth moving for roads and a bridge across coyote arroyo subsequent to his field work.

Bartel and others (1980) conducted a geophysical experiment utilizing controlled source audio-magnetotelluric (CSAMT) electromagnetic (EM) techniques between the Kirtland golf course and the west fence line of Manzano Base, in and adjacent to section $10, T 9 \mathrm{~N}, \mathrm{R} 4 \mathrm{E}$. This experiment was specifically designed to test the technique in an area where the Sandia fault was presumed to be present beneath the alluvial cover. The results indicate a sharp break in the depth to granite profile beneath the alluvium at approximately the common corners of sections 3 , 4,9 , and 10. The slope from the Four Hills granite outcrop to the east to this point is about $25^{\circ}$ northwest, almost the same as the slope on 


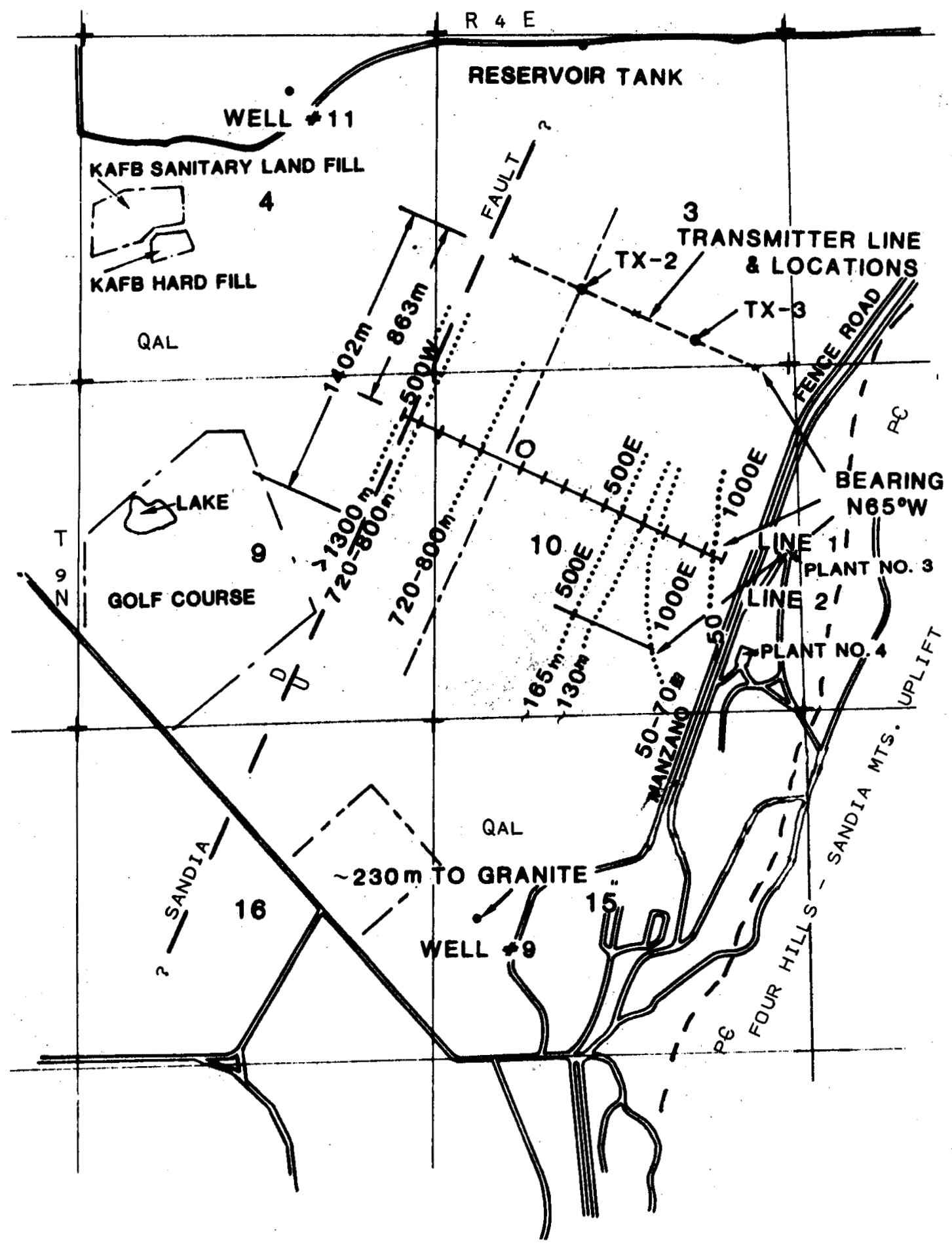

Figure 5. Controlled source audio-magnetotelluric (CSAMT) electromagnetic (EM) geophysical experiment. Sandia fault identified by long dashed line, downthrown to the northwest. Depth to basement (granite) in meters shown by dotted lines. Qal: Quaternary alluvium; pe: Precambrian granite. (Adapted from Bartel and others, 1980 in Riddle and Grant, 1981). 
the exposed uplift itself, suggesting that the Four Hills granite is simply buried beneath the alluvial cover. CSAMT data indicate a sharp break in slope occurs in the northwest corner of section 10 where the depth to basement (granite) increases from about $2,625 \mathrm{ft}(800 \mathrm{~m})$ to more than $4,265 \mathrm{ft}(1,300 \mathrm{~m})$ in a horizontal distance of less than $325 \mathrm{ft}$ $(100 \mathrm{~m})$. The investigators conducting the experiment interpret this break as the trace of a major fault (Figure 5).

Parker (this report, Appendix A) conducted several detailed gravity traverses on the base. The survey lines, identified by the dotted lines on Plate 1 and Figure 3, were selected to cross the presumed Hubbell Springs and sandia faults at approximately right angles. Sharply defined breaks in the gravity profiles in the southern part of the base coincide with the trace of the Hubbell springs fault. The northern profiles, however, show smooth curves with gravity values decreasing steadily to the west. These data reflect greater depths to basement and a substantial increase in thickness of valley fill sediments westward, bu't show no abrupt slope changes that could represent and define the subsurface position of the sandia fault. The profiles instead suggest a low angle fault dipping into the basin or buried topography rather than the single high angle fracture or series of steeply dipping step faults expected in this area.

The question of interpretation of gravity data along the presumed master faults bounding the Rio Grande rift where closely spaced contours occur has been addressed by Cordell (1979). Detailed profiles he obtained that cross these steep linear gravity gradients in other parts of the Albuquerque Basin resemble the data acquired by Parker on Kirtland AFB. The gentle, unbroken slope of the gravity cross sections require the basin boundary fractures to be interpreted as essentially planar surfaces dipping about $35^{\circ}$ toward the basin. The smooth curve of the profile, its apparent low angle, and lack of characteristic breaks together with densely spaced observation points 0.1 to $0.2 \mathrm{mi} / 0.16$ to $0.32 \mathrm{~km}$ on the base) preclude interpretation of high angle master or step faults if there are no other considerations.

Cordell (1979) suggests the gravity data require only one large fault and that the dip of the fault is gentle if the (gravity) density contrast is constant. If, however, the valley fill sediments close to the mountain uplifts (and the bounding faults) are coarser and more poorly sorted than those farther away, then a subsurface gradational density contrast is established and the bounding fault can be interpreted as a steeply dipping one. The interpretation favored by cordell is that the regional fault system in the Albuquerque Basin comprises "a relatively small number of large, widely spaced, high angle (at shallow levels) master faults that are identified by long, linear, large-amplitude gravity gradients, (complimented by) numerous secondary faults that are essentially large slump features sympathetic to the master faults." The concept of the master basin bounding faults together with their subsurface configuration could be tested by means of a detailed seismic reflection profile across one or more of the steep, linear gravity gradients.

Cordell (1979) admits that "the concept of a master fault is essentially speculative, consistency with the gravity data being a necessary, but not a sufficient, condition." Many geologists, however, would agree that the concept of large, extensive basin bounding faults is a logical interpretation of structural conditions and the steep, linear gravity gradients obtained by Cordell (1976), Cordell and others (1978), and Aiken and others (1978) support this explanation (see

Figure 4). It is unlikely, however, that the question will be 
resolved without detailed seismic reflection profiles across the assumed faults or deep drilling near a fault on its basinward, downthrown side.

The "Travertine Hills"

Feth and Barnes (1979) define travertine as "a carbonate-mineral deposite dominated by calcium carbonate, formed through the agency of spring water." These authors describe extinct travertine deposits occurring as much as hundreds of meters above present levels of spring activity or without any nearby springs present:

"(Deposits of travertine) have potentials for interpretation of ancient hydrologic systems, rates of downcutting, or rates of tectonic uplift that remain virtually unexploited... (and) imply hydrostatic heads that have long since vanished... Travertine seems to be a geological'y transient phenomenon, subject either to removal by erosion or to burial and disappearance... Many travertine deposits are known to be on or close to faults. Their occurrence in otherwise structurally featureless alluvial valleys may, therefore, suggest the possibility of a hidden fault... The temperature of spring water listed as actively depositing travertine ranges from $41^{\circ} \mathrm{F}$ to $205^{\circ} \mathrm{F}\left(5^{\circ} \mathrm{C}\right.$ to $\left.96^{\circ} \mathrm{C}\right)$, but the greatest concentration is in the range from $50^{\circ} \mathrm{F}$ to $86^{\circ} \mathrm{F}\left(10^{\circ} \mathrm{C}\right.$ to $\left.30^{\circ} \mathrm{C}\right)$.

"Possibly the most common mode of formation of travertine is from leaching of calcium carbonate from rocks by ground water and subsequent deposition of travertine in stream channels...Calcium carbonate dissolved in a $\mathrm{CO}_{2}$-rich water may reprecipitate when $\mathrm{CO}_{2}$ is lost from solution after the ground water enters a stream channel... The fundamental cause of the accumulation is a greater time rate of supply of unstable (supersaturated) solution per unit area of substrate where the water velocity is greater. The maximum development in stream channels is a series of pools separated by rims of travertine."

Bargar (1978) describes the origin and composition of travertine deposits associated with Mammoth Hot Springs in Yellowstone National Park, Wyoming:

"Chemical and isotopic analysis of hot-spring waters supply important information about the history of the thermal water. Cold, dilute meteoric water (rain or snow) has a distinctive hydrogen and oxygen isotopic composition that distinguishes it from water that comes from magmas deep in the earth. Such information suggests that over 95 percent of the hot-spring water emerging in Yellowstone National Park probably originates as meteoric water.

"The thermal water beneath the Mammoth travertine deposits contains a large amount of dissolved gas, mainly carbon dioxide. Measurements... showed that the confining pressure necessary to keep the gas dissolved in the water is greater than $6 \mathrm{~kg} / \mathrm{cm}^{2}\left(2 \mathrm{lb} / \mathrm{in}^{2}\right)$. As the water flows upward through a labyrinth of channels in the old fractured terraces, the confining pressure gradually decreases, and hot gas, consisting mainly of $\mathrm{CO}_{2}$ separates and escapes at the surface. The effect is similar to removing the 
cap from a carbonated soft drink. The escape of $\mathrm{CO}_{2}$ causes the water to become supersaturated with calcium carbonate $\left(\mathrm{CaCO}_{3}\right)$, which precipitates out of solution to form travertine, mainly in the form of the mineral calcite."

Travertine deposits are abundant on Kirtland AFB. Reiche (1949) noted that, "At Coyote Springs, formerly known as Soda Springs, near the center of the north half of section $24, T 9 \mathrm{~N}, \mathrm{R} 4 \mathrm{E}$, a terrace of travertine has been formed by waters emitting carbon dioxide, which rise under low pressure thorugh the crush zone adjacent to a fault. Mass movement or cloudburst run off repeatedly introduced angular quartzite fragments during terrace growth." With the exception of a small spring in the Manzano Mountains 10 to $12 \mathrm{mi}$ (16 to $19 \mathrm{~km}$ ) south of the base, Reiche found no other springs in the area depositing travertine, although several, unlike coyote spring which is apparently in a granite terrain, issue directly from limestone. The geologic map by Myers and McKay (1970) shows the travertine deposit described by Reiche, but no others.

In describing Tertiary valley fill deposits (Santa Fe Formation), Reiche (1949) states:

"In the area of this paper Tertiary beds are of limited distribution and are generally mantled by Quaternary debris. However, in sections 27,28 , and $33, T 9 \mathrm{~N}, \mathrm{R} 4 \mathrm{E}$, several low hills and a flat district to the east are formed of illsorted sandy coarse Tertiary gravels (fanglomerate). These are essentially impermeable, owing to an interstitial clay fraction which is about half calcite and half kaolinitic clay. Along their western margin the gravels are dragged to easterly dips as high as $48^{\circ}$, exposing a section 1,100 ft thick; its extensions to east and west are masked by Quaternary gravels and coluvium which hide faults.

"The lower part of these Tertiary beds has pebbles, cobbles, and, rarely, boulders derived from the Magdalena (Madera) formation and lacks fragments of Precambrian derivation; the upper part has abundant Precambrian debris. The Magdalena (Madera) crops out in a fault block $2 \mathrm{mi}$ (3 $\mathrm{km})$ wide, less than a mile $(\mathrm{km})$ east of the gravels. Apparently drainage was established across this block while the gravels were accumulating."

Investigations conducted for this project confirm that none of the springs on the east mesa that apparently mark the trace of the Hubbell springs fault are depositing travertine. However, travertine deposits are far more widespread on Kirtland AFB than Reiche or any other investigator determined. The Tertiary gravels described by Reiche (above) are massive, extensive travertine deposits.

One of the more significant results of our study is the identification and mapping of large deposits of travertine on the base. Travertine is known to be abundant on the west wide of the Albuquerque Basin bounding the east side of the Lucero uplift, some 17 to $20 \mathrm{mi}$ (27 to $32 \mathrm{~km}$ ) west of Belen and Los Lunas (Kelley, 1977; Titus, 1963; Kottlowski, 1962). On the east side of the basin travertine was known to exist only as minor deposits located just west of Placitas on the north end of the Sandia Mountains and the small outcrop at coyote Spring described by Reiche (1949) and mapped by Myers and McKay (1970). 
The low hills in sections 27,28 , and 33, T $9 \mathrm{~N}, \mathrm{R} 4 \mathrm{E}$, described by Reiche (1949) as Tertiary gravels are actually travertine mounds rising some 100 to $125 \mathrm{ft}(30$ to $38 \mathrm{~m})$ above the mesa, covering about 240 acres ( 97 hectares). Travertine is also abundant in the channel of Coyote arroyo from about $100 \mathrm{yds}(91 \mathrm{~m})$ west of the bridge over the arroyo in section $22, T 9 \mathrm{~N}, \mathrm{R} 4 \mathrm{E}$ to a point near a small spring in the arroyo bed almost $1 \mathrm{mi}(1.6 \mathrm{~km})$ east. The travertine is well exposed at this location immediately under and adjacent to the bridge and in ledges and benches on both sides rising about $30 \mathrm{ft}(9 \mathrm{~m})$ above the channel. Excellent exposures of travertine in the mounds (hills) are found in the road cut about $3,000 \mathrm{ft}(914 \mathrm{~m})$ west of the west entrance to the solar power tower complex, and in the east-west arroyo separating the two southernmost hills. The hills are aligned in a north-south direction, offset less than one-half $\mathrm{mi}(0.8 \mathrm{~km})$ east from the prominent bench of the Hubbell springs fault scarp on the Isleta Indian Reservation some $2.5 \mathrm{mi}(4 \mathrm{~km})$ south.

Thickness of the travertine is unknown. Its base was encountered in only one location, about 60 to $100 \mathrm{yds}$ (55 to $91 \mathrm{~m}$ ) northeast of the mouth of a small arroyo behind an earthen bunker, northwest of a large water tank in the southeast quarter of section 28. Here, a resistant ledge of travertine unconformably overlies a weathered pinkish-brown Precambrian quartzite. The travertine is only about $30 \mathrm{ft}(9 \mathrm{~m})$ thick at this point, considerably less than the more than $100 \mathrm{ft}(30 \mathrm{~m})$ exposed in the travertine hills south of the "water tank arroyo."

All of the travertine formations are conglomeratic. Those in the drainage of coyote arroyo contain clasts that are predominantly Precambrian granites, schists, and quartzites, while those in the low hills have a preponderance of Paleozoic limestones, sandstones, and shales. Clasts range in size from sand-size material through boulders as large as 12 in $(30 \mathrm{~cm})$ in diameter. It would be difficult to assign any significant to the conglomerate components in terms of attempts to date the accumulations of travertine; the beds containing a majority of Precambrian clasts are adjacent to the Tijeras fault where older rocks were probably exposed prior to the beginning of travertine deposition, and the travertine hills are within $1 \mathrm{mi}(1.6 \mathrm{~km})$ of Paleozoic outcrops on the Hubbell Bench. Boulder erratics of Precambrian quartzite up to $6 \mathrm{ft}(2 \mathrm{~m})$ in diameter are found on the north slope of the northernmost travertine hill, west of the water tank in section 28, that imply an enormous load capacity of streams of periodic floods from the mountains to the east.

The occurrence of travertine is not, by itself, evidence of a hydrothermal regime. In connection with other data, however, it lends support to a geological basis for predicting one. The travertine hills or mounds are at the intersection of the Hubbell springs, Tijeras, and presumed Sandia faults (Plate 1 and Figure 3 ). Their occurrence is indicative of an underlying major fault system thorough and along which large volumes of water freely migrated. A model of the hydrology would suggest that a previous system existed that coursed meteoric water through the Santa Fe Formation in the rift to a depth where it was subjected to substantially warmer temperatures and then rose to the surface by convection currents along the master faults. It would be logical to expect the focal point for this activity to occur at the intersection of the tectonically active Tijeras and Hubbell springs-sandia faults. Later events, perhaps including plugging of the fault permeabilities by travertine deposition, a change in the regional hydrologic gradient, and masking of the thermal water by low temperature meteoric water cascading from the mountains across the basin fault as described by Titus (1963), resulted in cessation of spring and possible thermal activity at this 
site. Morgan and others (1981) discuss a similar concept to account for surface and near surface hydrothermal anomalies where ground water in the basins of the Rio Grande rift discharges across subsurface constrictions at their downstream ends. Figure 6 is a schematic cross section to illustrate these relationships on the base.

\section{Temperature}

Recent investigations of the geothermal characteristics of the Rio Grande rift have produced a great deal of information relating to temperatures in the rocks and fluids of the basins. Until a geothermal prospect is developed, however, much of this research data remains speculative and inconclusive.

Reiter and others $(1975,1978)$ have analized heat flow data and determined that a major geothermal anomaly with heat flow values greater than 2.5 heat flow units (HFU) is coincident with the westerh part of the Rio Grande rift. These investigators suggest that the anomaly may overlie deep crustal fractures that penetrate the upper mantle of the earth through which magmatic fluids approach the surface. As evidence they site recent volcanic activity and thermal springs on the rift's western side and general absence of the same features on its eastern side, implying that extensional tectonic activity has been primarily concentrated on the rift's west wide.

Chapin (1971) observed that rifting began at least 18 million years ago and that concurrent volcanism and hot spring activity occurs mainly along the rift's medial axis and west side. He attributes this to stretching of the crust and normal faulting on the west side relieving subcrustal pressures and providing avenues for ascent of magmas and hydrothermal solutions, while longitudinal faults on the east side are relatively tight and unconducive to magmatism.

A magmatic heat source beneath the rift is described by sanford (1978) in terms of geophysical evidence for a shallow lens of fluid magma beneath the Socorro area. Reilinger and others (1980) extend Sanford's currently active magma body to beneath Albuquerque, citing evidence that includes anomalously high earthquake activity (including swarms) and geodetic evidence for historic crustal doming above the magma lens. These researchers believe the magma to be located about $12 \mathrm{mi}$ (20 km) beneath the surface and to be inflating at a rate of about $2 \times 10^{-2}$ $\mathrm{km}^{3} / \mathrm{yr}\left(7,000 \mathrm{ft}^{3} / \mathrm{yr}\right)$, with continuous surface uplift averaging about $5 \mathrm{~mm} / \mathrm{yr}(0.2 \mathrm{in} / \mathrm{yr})$. Towle (1980), analizing the geomagnetic variation field across the Rio Grande rift, states that the evidence for magmatic intrusion in the central rift between $34^{\circ}$ to $36^{\circ}$ north latitude (Kirtland AFB is at $35^{\circ} \mathrm{N}$ lat) is compelling. Jaksha and others (1980) measured earthquake swarms in 1978 and 1979 generated about $1.5 \mathrm{mi}$ $(2.5 \mathrm{~km})$ west of the Albuquerque volcanoes on the west mesa. They interpret the movement to be associated with a north-south, high angle, west dipping normal fault that projects to the surface exposure of the fissure along which the volcanoes erupted. This evidence could also be interpreted to be associated with inflation or deflation of a magma body.

Anomalous temperatures and temperature gradients in the Albuquerque area are discussed by Parker and Jiracek (1981), including higher than normal temperatures in city water wells on the west mesa and the results of a study that identified an area with temperature gradient values exceeding $120^{\circ} \mathrm{C} / \mathrm{km}\left(7.6^{\circ} \mathrm{F} / 100 \mathrm{ft}\right)$ on the mesa $5 \mathrm{mi}(8 \mathrm{~km})$ west of Albuquerque. According to these investigators, the average temperature gradient in the Rio Grande rift is $35^{\circ} \mathrm{C} / \mathrm{km}\left(2.5^{\circ} \mathrm{F} / 100 \mathrm{ft}\right)$. 


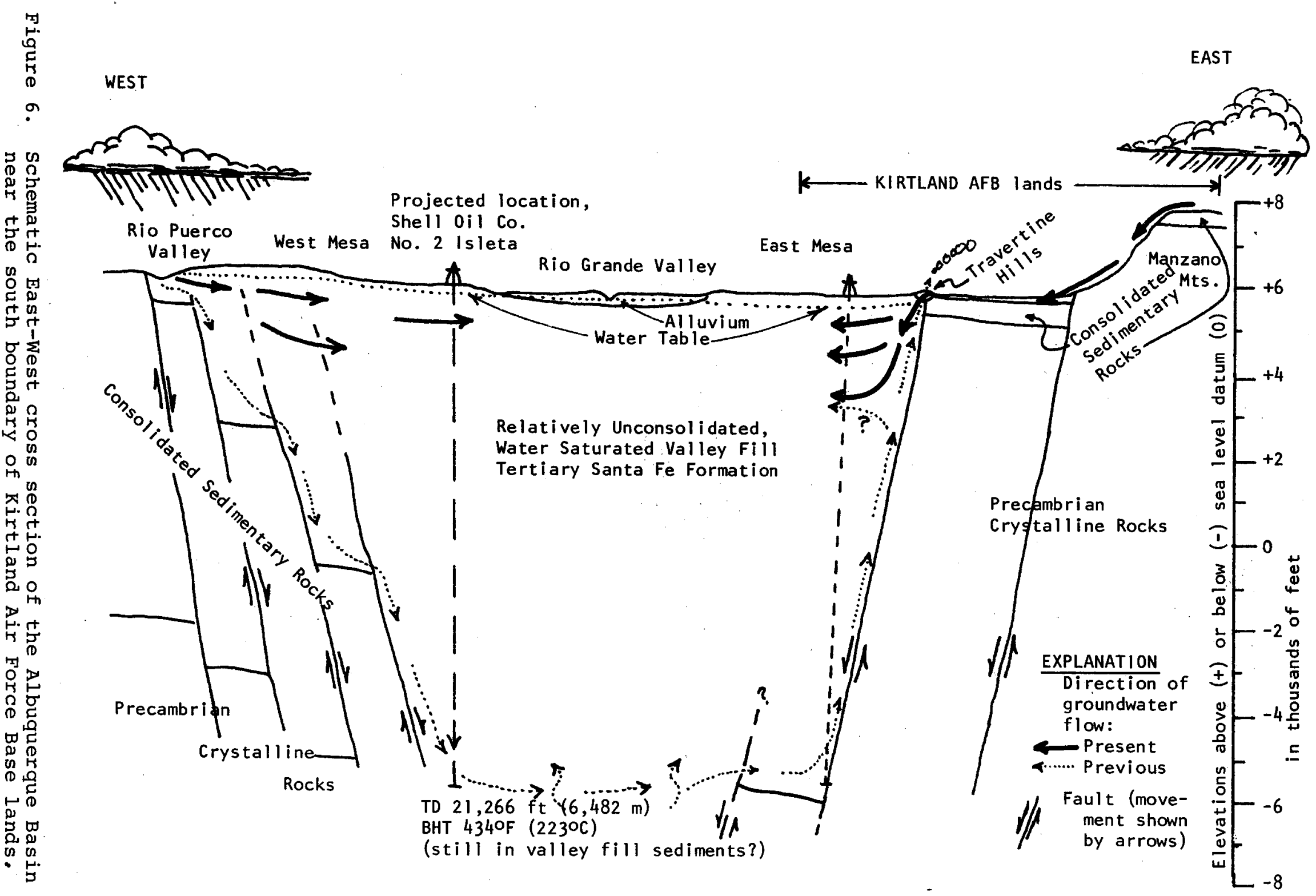


The heat flow data collected by Reiter and others (1975) in the immediate Albuquerque area are limited to three locations, all on Kirtland AFB lands. These imply lower than normal HFU's and were used by the investigators as a basis for limiting the Rio Grande rift's major geothermal anomaly to the west mesa where higher than normal heat flow was measured. The procedure used to arrive at heat flow values was to multiply measured geothermal gradients from drill holes by the thermal conductivity of the rocks penetrated by the drill holes. One of the drill holes is in section $4, T 9 \mathrm{~N}, \mathrm{R} 4 \mathrm{E}$ and the other two are in section 6, T $8 \mathrm{~N}, \mathrm{R} 5 \mathrm{E}$ (personal communication, M. Reiter, September 12, 1980), in areas on the base where the cascade effect of cold meteoric water from the mountains would be expected to mask any valid thermal anomaly. These data, then, are probably inconclusive or invalid for defining geothermal values.

Swanberg and Morgan (1980) suggest that on the basis of geochemical techniques applied to groundwater in the Albuquerque area the most promising part for geothermal development is located on the west mesa between the volcanoes and the Rio Grande. They state that there is no geochemical data to suggest geothermal resources east of I-25. Swanberg describes the essence of geochemical methods in geothermal analysis is that the solubility of various elements (or ratios of elements) is temperature dependent and that the concentrations become established within the geothermal reservoir and do not change as the water migrates to the surface sampling point. By plotting the concentrations (or ratios) against known reservoir temperature, empirical curves can be established which relate concentrations (or ratios) to the reservoir temperature. The technique is known as geothermometry and swanberg suggests that although the most common use of geothermometers is to apply them to hot spring waters to estimate reservoir base temperatures, they can also be applied to non-thermal waters and the results used to detect the presence of a geothermal component in groundwaters. These procedures were used to identify the west mesa prospects. The authors also applied a theoretical silica heat flow method to the study area to supplement the traditional points used by Reiter and others (1975). They found that data derived from analysis of water from the city's east mesa wells yielded unrealistically high values that did not conform to the results of their geothermometry experiments or Reiter's heat flow data and were, therefore, suspect.

Riddle (Riddle and Grant, 1981) collected well and spring water samples on and in the vicinity of Kirtland AFB. Detailed and comprehensive chemical analyses of these samples were conducted. These data are presented in their report and suggest no significant geothermal parameters were identified in the samples examined.

Although a large body of geophysical evidence associated with seismicity and presumed shallow magma bodies suggests higher than normal temperatures should be encountered in the subsurface beneath Albuquerque, geochemical data is supportive for the west mesa area and contradictive for the east mesa. Of significance, however, is that if appropriate geologic conditions of structure and stratigraphy are present in the Albuquerque-Kirtland AFB area (basically a thick suite of porous and permeable valley fill sediments), there is no requirement for exotic and anomalous geothermal regimes. Normal subsurface thermal gradients are more than adequate to supply sufficient Btu's for large scale space heating and cooling requirements.

Kelly (1974) indicated that $302^{\circ} \mathrm{F}\left(150^{\circ} \mathrm{C}\right)$ temperatures should be encountered in the Albuquerque Basin at depths of about 17,000 ft $(5,182 \mathrm{~m})$. He also estimated that wells completed to the $12,000 \mathrm{ft}$ 
$(3,658 \mathrm{~m})$ level would yield about 500 gallons per minute (gpm) (32 liters per second). Production of water from the valley fill would not involve pumping from great depths. Since the aquifer is essentially unconfined and the water table is at the surface at the level of the Rio Grande and only a few hundred feet below the surface at the higher parts of the east mesa, the hydrostatic head or column would bring the deeper water to the water table level in a cased wellbore.

Deep wells drilled in the basin provide the only definitive data regarding sub-surface conditions of sediment type, thickness, and temperature. The several shell oil company oil and gas tests drilled in the vicinity of Albuquerque (Figure 7) exhibit no abnormal sub-surface temperatures and a geothermal gradient of about $2^{\circ} \mathrm{F} / 100 \mathrm{ft}+60^{\circ} \mathrm{F}$ ambient temperature $\left(\right.$ about $\left.35^{\circ} \mathrm{C} / \mathrm{km}\right)$.

\section{Depth to Basement}

Depth to basement in the Albuquerque Basin can be defined as the vertical distance between the surface and Precambrian rocks. It comprises, therefore, all the sedimentary section including not only the relatively unconsolidated valley fill but also the consolidated, lithified Mesozoic and Paleozoic rocks between the base of the Tertiary and top of the Precambrian. Depth to basement is zero where Precambrian rocks are exposed, as in the Four Hills foothills and Manzanita Mountains on Kirtland AFB. It could be in excess of $26,000 \mathrm{ft}(7,925 \mathrm{~m})$ at the Shell oil Co. No. 2 Isleta well in the Albuquerque Basin just $2 \mathrm{mi}$ $(3 \mathrm{~km})$ west of the Pueblo and $10 \mathrm{mi}(16 \mathrm{~km})$ west of the base.

Knowledge of the thickness of the Tertiary valley fill is crucial to an exploration program for geothermal resources on Kirtland AFB. The Tertiary Santa Fe Formation is the aquifer that, if thick enough, will contain water heated by normal thermal gradients to temperatures usable for significant space heating and cooling applications.

In connection with hydrologic investigations by the USGS in the Albuquerque Basin, Birch (1980) attempted to determine the subsurface geology of the Albuquerque Basin by analysis and interpretation of gravity anomalies. He produced a number of profiles and sediment thickness maps that contribute a great deal to understanding the subsurface relationships in the basin, using all available deep well control in and near the basin for geologic control. It appears, however, that in separating sedimentary units in the basin on the basis of gravity densities, Birch may have interjected a major error in attempting to separate "Neogene" from "Paleogene" sediments. "Neogene," according to Birch, are "post-rift" rocks and he places the base of this layer at the top of verious Eocene formations: Galisteo, San Jose, and Baca. The latter, defined as "Paleogene," have been included with the basin's Cretaceous and Jurassic sediments. Birch acknowledges that, "In practice it is not always easy to determine the base of this layer due to omissions in the well reports or differences in terminology."

Illustrative of the difficulties Birch's arbitrary selection of valley fill sediments presents in modeling and interpretation is that in the Shell Oil Co. No. 1 Isleta in section $7, T 7 \mathrm{~N}, \mathrm{R} I \mathrm{E}$, there are more than $12,000 \mathrm{ft}(3,658 \mathrm{~m})$ of "valley fill" overlying the Cretaceous. Birch assigns the upper $5,300 \mathrm{ft}(1,615 \mathrm{~m})$. or so to the Santa Fe Formation and includes the other approximately $6,700 \mathrm{ft}(2,042 \mathrm{~m})$ to the gravity layer that includes cretaceous and Jurassic strata. This artificial delineation of stratigraphic units may fit the mechanical requirements of the geophysical model, but it makes little or no sense geologically. 


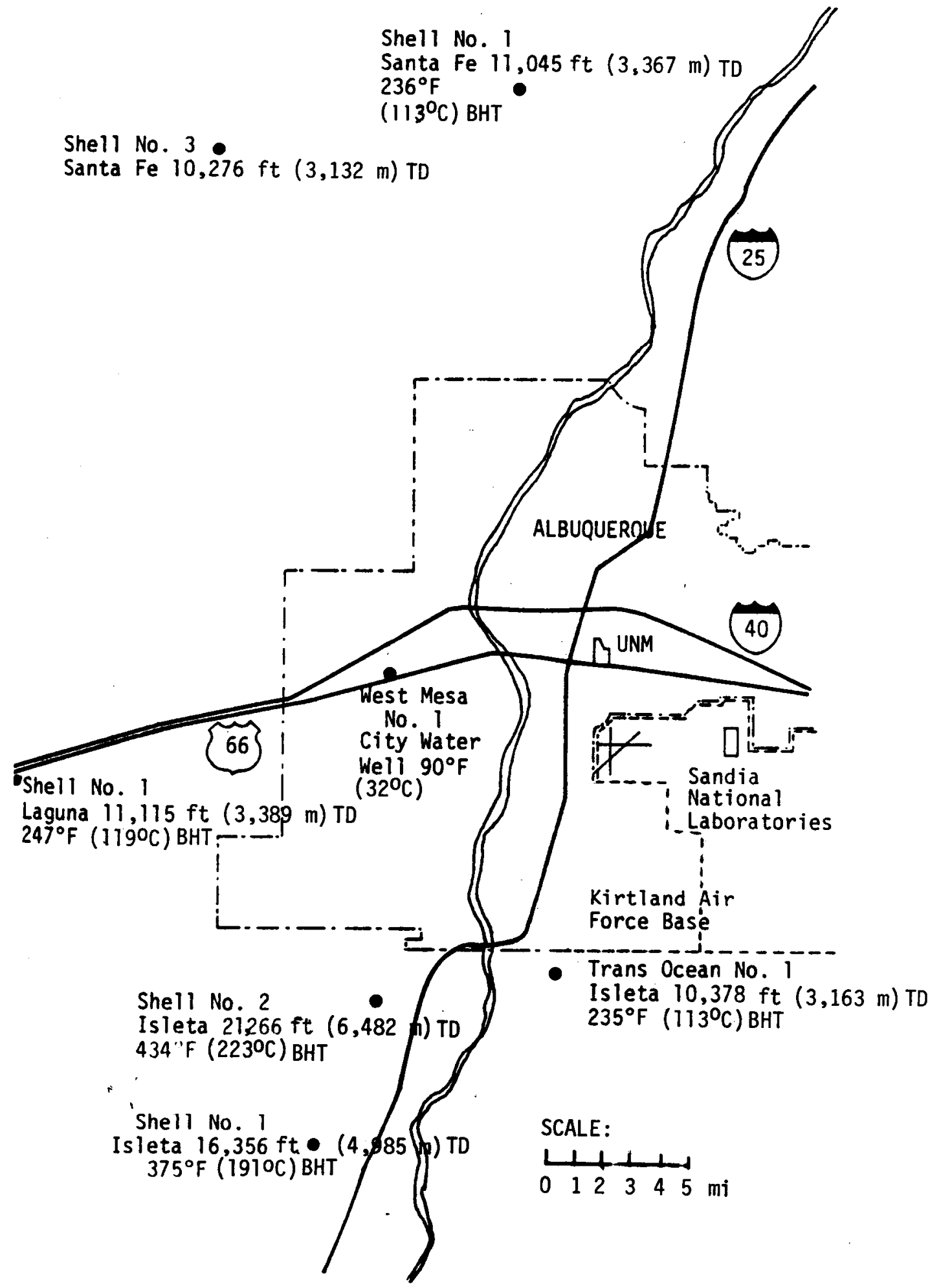

Figure 7. Deep wells in the vicinity of Albuquerque. (TD: Total Depth; BHT: Bottom Hole Temperature.) 
Although they may be a result of different periods of in-fill, all of the Tertiary rocks above pre-basin deposits and terrains as old as Precambrian are tectonically related, lithologically similar, are probably hydrologically interconnected, and can be collectively designated valley fill (or basin-fill). Pre-Santa Fe Tertiary sediments are difficult to recognize in the subsurface and where they are differentiated in surface exposures they are less than 3,000 ft $(914 \mathrm{~m}$ ) thick (Relley,. 1977).

of primary importance in Birch's study is his depth to the Precambrian basement map of the Albuquerque Basin (Figure 8). Because this map incorporates all the gravity densities and sedimentary layers above the Precambrian, the significance of the valley fill thickness miscalculation is lost because it is incorporated in all the sedimentary suites. The map suggests that the area of Kirtland AFB west of the Hubbell springs-Sandia fault line has Precambrian rocks buried at a subsea datum of $-9,840$ to $-11,484 \mathrm{ft}(-3,000$ to $-3,500 \mathrm{~m})$. Added to an average surface elevation above sea level on the base of $5,400 \mathrm{ft}(1,646 \mathrm{~m})$, the depth to basement on Birch's map is 15,240 to $16,884 \mathrm{ft}(4,646$ to $5,146 \mathrm{~m})$ in this area. Well data and other information (Kelley, 1977) indicates that the Cretaceous to Precambrian interval is about $5,000 \mathrm{ft}(1,524 \mathrm{~m})$ thick, leaving a valley fill suite of about 10,000 to $12,000 \mathrm{ft}(3,048$ to $3,658 \mathrm{~m})$.

Additional geophysical data relating to depth to basement on the base was obtained through an experiment conducted November 26, 1980 . As part of a routine testing program the Civil Engineering Research Facility of UNM (CERF) detonated a large quantity of explosives in section $36, T 9 \mathrm{~N}, \mathrm{R} 3 \mathrm{E}$. The blast was measured and recorded by equipment furnished and monitored by the USGS Albuquerque Seismological Laboratory under the guidance of geophysicist Lawrence H. Jaksha. The location of the recording stations is shown on Figure 3 and the refraction results are described in Table 2. Although the experiment was limited in scope, somewhat crude, and, according to Jaksha (personal communication February 6, 1981), "The estimates of the thickness of the sedimentary section have a lot of assumptions behind them, and should be used as first approximations only," they do contribute to our knowledge of the basin's development and configuration.

Like the temperature data, geophysical information on subsurface conditions of structure, sediment thickness, and depth to basement in the Albuquerque Basin is somewhat subjective and inconclusive. Birch's basement map interpreted from gravity data (Figure 8) is accurate where deep well data exists but may incorporate substantial errors elsewhere. The shell No. 2 Isleta in section 16, T $8 \mathrm{~N}, \mathrm{R} 2 \mathrm{E}$, for instance, may have 60 percent more depth to basement than the map indicates. It should be realized that geological and geophysical data and its interpretation in this region, though far more advanced, extensive, and balanced than just 10 or so years ago, still lacks maturity. Additional well data coupled. with more sophisticated, focused, and expensive seismic techniques will lead to other conclusions and new interpretations to unravel the complexities of the Albuquerque Basin's structural, sedimentary, and hydrologic history. 


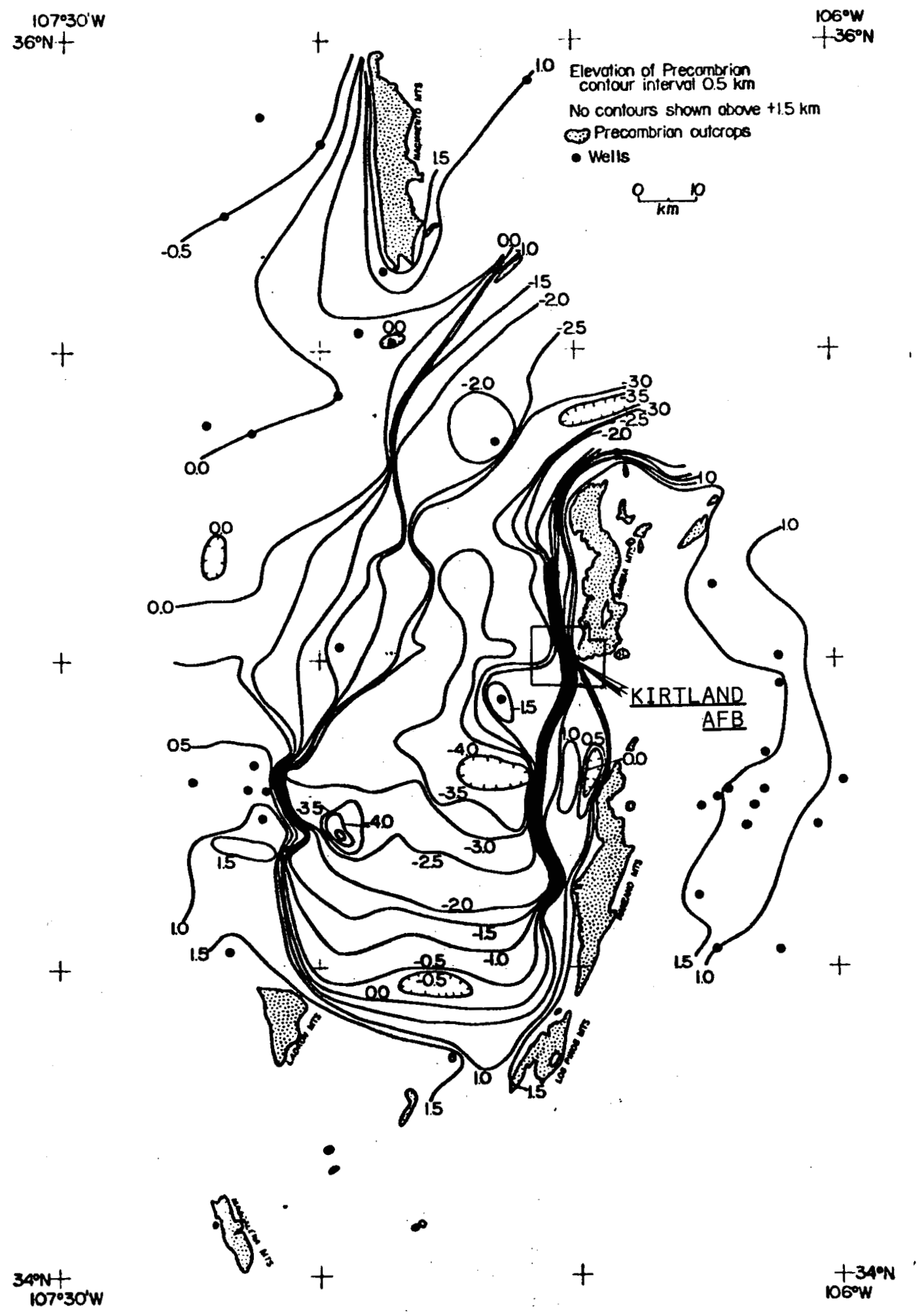

Figure 8. Elevation of Precambrian basement relative to sea-level datum in the Albuquerque Basin. Contour interval $0.5 \mathrm{~km}(1,640 \mathrm{ft})$. Dots show locations of Precambrian wells. Source: Birch, 1980. 
Table 2. Refraction Geophysical Experiment, CERF Explosion, Kirtland AFB, November 26, 1980

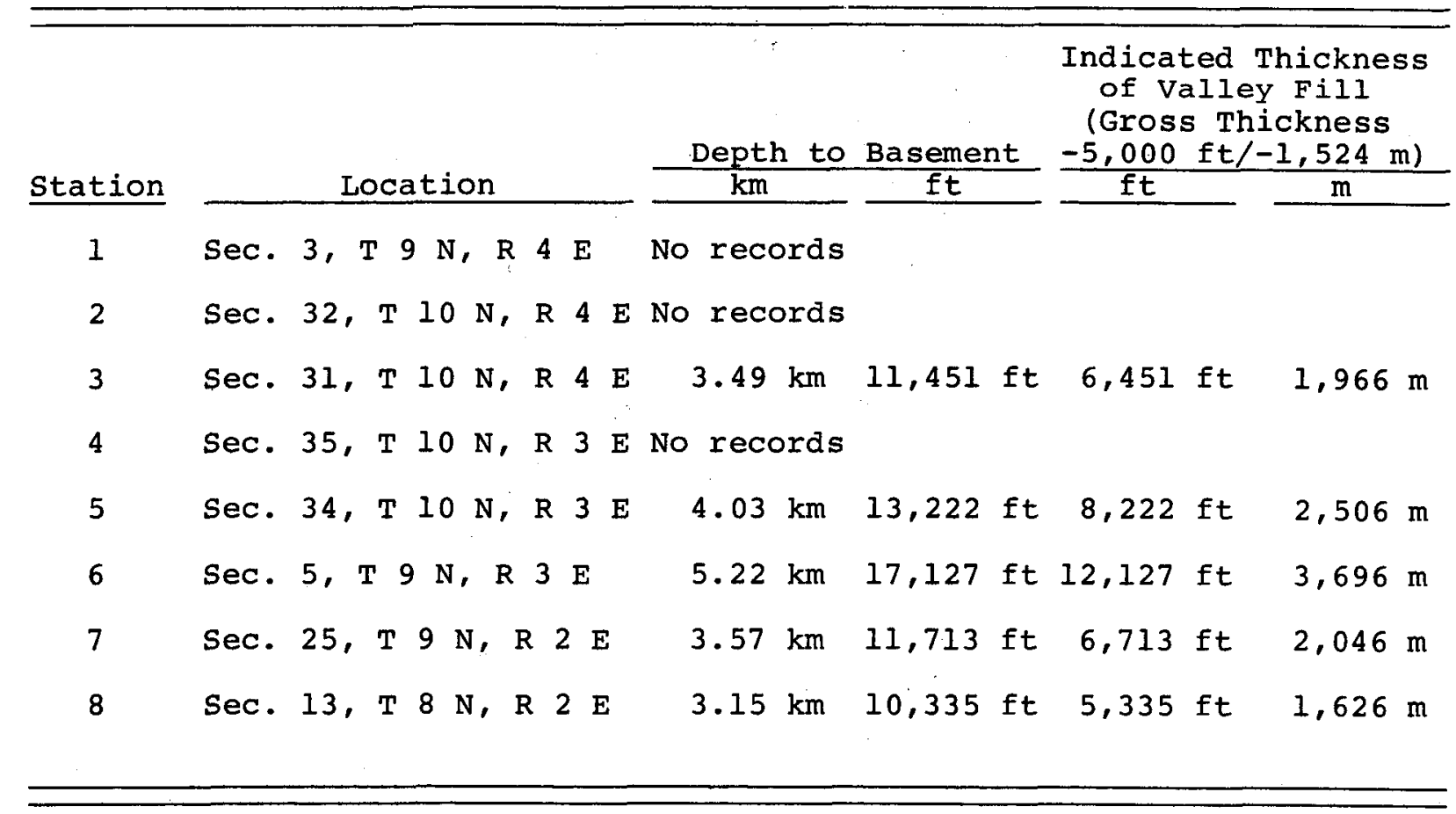




\section{CONCLUSIONS}

Geological, geophysical, and hydrological data in the Albuquerque Basin, though insufficient in some areas and contradictory and inconclusive in others, are adequate to predict the existence of an extensive intermediate $\left(200^{\circ} \mathrm{F} / 93^{\circ} \mathrm{C}\right.$ ) to high-temperature (in excess of $300^{\circ} \mathrm{F} / 149^{\circ} \mathrm{C}$ ) geothermal system beneath portions of Kirtland AFB lands. The base is the focal point for a number of major tectonic events that provide evidence for a possible anomalous hydrothermal convective regime near the surface, as well as a deeper system in an unconfined aquifer of relatively unconsolidated basin-fill sediments that exceed $20,000 \mathrm{ft}(6,096 \mathrm{~m})$ in thickness in a well $11 \mathrm{mi}(18 \mathrm{~km})$ southwest.

Virtually all of the principal tectonic events that formed the east side of the Rio Grande rift, the Albuquerque Basin and the adjoining Sandia, Manzanita, and Manzano mountain ranges occurred on and have profoundly affected Kirtland AFB lands. The Tijeras fault that has beeh tectonically active and experiencing movement from the Precambrian to the present bisects the base in a northeast-southwest direction. Where it intersects the Hubbell springs fault, believed to be the major northsouth rift bounding fault on the east side of the basin, in the vicinity of sections 28 and $33, \mathrm{~T} 9 \mathrm{~N}, \mathrm{R} 4 \mathrm{E}$, there is an extensive travertine deposit.

Although travertine is not by itself conclusive evidence of a hydrothermal regime, and inactive thermal spring areas are not necessarily indicative of near surface useful heat, its occurrence superimposed on major fault systems warrants further investigation. It is apparent that large volumes of water freely migrated along these faults that issued as travertine depositing springs. A model of the hydrology would suggest that this preexisting system coursed meteoric water through the valley fill sediments of the Rio Grade rift's Santa Fe Formation where it was subjected to substantially warmer temperatures at depth and then rose to the surface by convection currents along the master faults. It is logical for the focal point of this activity to be at the intersection of the tectonically active Tijeras and Hubbell springs faults.

Later events, perhaps including plugging of the fault permeabilities by chemical deposition, a change in the regional hydrologic gradient, and masking of the thermal water by low temperature meteoric water cascading from the nearby mountains across a shallow, relatively impermeable structural bench before plunging into the basin across the boundary fault, resulted in cessation of spring and possible thermal activity at this site. Although strong thermal spring activity is geologically short lived and probably represents a minor phase of a more extensive period of host rock heating and cooling, it should be recognized that a great deal of useful heat would continue to be stored in a host rock and associated aquifers long after surface manifestations have disappeared. The basinward side of the travertine deposits, then, is a primary prospect for evaluating the possibility of the occurrence of relatively near surface hot water.

A large body of geophysical evidence associated with seismicity and presumed shallow magma bodies suggests higher than normal temperatures should be encountered in the subsurface beneath Albuquerque. Geochemical data from water analysis, temperature gradient experiments, and terrestrial heat flow measurements appear to support this premise for areas west of the Rio Grande and are contradictive and inconclusive for the east mesa areas. 
Of significance is that if a thick suite of porous and permeable valley fill sediments underlies the Albuquerque-Kirtland AFB region there is no requirement for exotic and anomalous geothermal regimes supported by mechanical and theoretical data. Normal subsurface thermal gradients are more than adequate to supply sufficient Btu's for large scale space heating and cooling requirements. "Depth to basement approximations from gravity and refraction geophysical research and experiments indicate the Albuquerque Basin and the western part of the base to be underlain by between 6,500 to $12,000 \mathrm{ft}(1,981$ to $3,658 \mathrm{~m})$ of water saturated valley fill deposits.

Deep wells drilled in the basin provide the only definitive data regarding sub-surface conditions of sediment type, thickness, and temperature. Several Shell oil Company oil and gas tests drilled in the vicinity of Albuquerque-Kirtland AFB exhibit no abnormal sub-surface temperatures and show the valley fill sediments to be more than $21,000 \mathrm{ft}$ $(6,400 \mathrm{~m})$ thick. Normal temperature gradients of about $2^{\circ} \mathrm{F} / 100 \mathrm{ft}$ plus $60^{\circ} \mathrm{F}$ ambient background (about $35^{\circ} \mathrm{C} / \mathrm{km}$ ) would provide water temperatures in these sediments ranging from $260^{\circ} \mathrm{F}$ to $460^{\circ} \mathrm{F}\left(127^{\circ} \mathrm{C}\right.$ to $\left.238^{\circ} \mathrm{C}\right)$ at depths of 10,000 to $20,000 \mathrm{ft}(3,281$ to $6,562 \mathrm{~m})$.

\section{RECOMMENDATIONS}

Shallow Temperature Gradient Wells

Shallow temperature gradient holes, normally considered to be an effective and relatively inexpensive phase of geothermal reservoir definition, are not recommended for Kirtland AFB. Wells drilled east of the Hubbell springs fault will encounter groundwater in perched aquifers at shallow depths overlying consolidated, relatively impermeable bedrock. This water is immediately derived from rain and snowfall on the nearby mountains. Wells drilled west of the Hubbell springs fault will encounter groundwater that is the overflow from the perched aquifers to the east as it cascades over the fault into the thick Albuquerque Basin valley fill. Depending upon topography and surface elevations, the water table on Kirtland AFB west of the Hubbell springs fault is encountered at about 450 to $550 \mathrm{ft}(137$ to $168 \mathrm{~m})$ below the surface, about $4,900 \mathrm{ft}(1,494 \mathrm{~m})$ above sea level (U.S. Army Corps of Engineers, 1979). It is unlikely that wells drilled to less than 2,000 to $3,000 \mathrm{ft}(610$ to $914 \mathrm{~m}$ ) will obtain useful data above the zone of interference.

\section{Reflection Seismic Survey}

Existing geophysical data is inconclusive regarding sediment thickness and depth to basement. in the Kirtland AFB area. It is recommended that a commercial geophysical survey be conducted on the base using reflection or refraction techniques. Reflection techniques measure the energy or wave from an explosion or other seismic source which has been reflected (returned) from an acoustic-impedance contrast (reflector) or series of contrasts within the earth. The objective of most reflectionseismic work is to determine the location and attitude of reflectors from measurements of the arrival time of primary reflections and to infer from the reflectors the geologic structure and stratigraphy. A refraction survey maps geologic structure using head waves. Head waves involve energy which enters a high-velocity medium (refractor) near the critical angle and which travels in the high-velocity medium nearly parallel to the refractor surface. Head wave arrivals are identified in terms of time after the shot and of distance from the shot. The objective is to determine the arrival times of the head waves in order 
to map the depth to the refractors in which they traveled (Sheriff, 1973). The reflection seismic survey would be preferable since it would probably readily define and separate the dense precambrian granitic mass from the overlying Mesozoic and Paleozoic beds, as well as segregate the less dense valley fill from the other rocks. A Vibroseis technique that induces vibrations into the ground as the energy source to generate a wave train of controlled frequencies would probably be necessary and appropriate since it does not involve the use of explosives that may be unacceptable in the technical areas.

A minimum of 4 lines involving a total of about $24 \mathrm{mi}(39 \mathrm{~km})$ would be required to obtain definitive data:

1) $8 \mathrm{mi}(13 \mathrm{~km})$ from the northeast corner of section 2, T $9 \mathrm{~N}$, $\mathrm{R} 4 \mathrm{E}$, west to the west side of the Albuquerque International Airport in about the northwest corner of section $3, T 9 \mathrm{~N}$, R $3 \mathrm{E}$.

2) $5 \mathrm{mi}(8 \mathrm{~km})$ from the southeast corner of section 10, T $9 \mathrm{~N}$, $R 4 \mathrm{E}$, at about the west fence line of Manzano Base west to the southwest corner of section $12, T 9 \mathrm{~N}, \mathrm{R} 3 \mathrm{E}$.

3) $5 \mathrm{mi}(8 \mathrm{~km})$ west along Magazine/Isleta Rd. from its intersection with Lovelace Rd. in the northwest corner of section 35, T $9 \mathrm{~N}, \mathrm{R} 4 \mathrm{E}$, to the northwest corner of section $36, T 9 \mathrm{~N}, \mathrm{R} 3 \mathrm{E}$ on the McCormick Ranch site.

4) At least $6 \mathrm{mi}(10 \mathrm{~km})$ of connecting north-south line from the northeast corner of section $32, T 9 \mathrm{~N}, \mathrm{R} 4 \mathrm{E}$, to the Eubank Gate in the northeast corner of section $32, \mathrm{~T} 10 \mathrm{~N}$, $\mathrm{R} 4 \mathrm{E}$.

The described seismic program could be contracted for about $\$ 150,000$ to $\$ 200,000$, including interpretation of data.

Wel1s

Two exploration and development programs are recommended that involve drilling wells on the base. The first would be to evaluate the possibility of encountering a residual near-surface hydrothermal system that may have been responsible for the deposition of the large travertine deposits in sections 28 and $33, T 9 \mathrm{~N}, \mathrm{R} 4 \mathrm{E}$. This would necessitate drilling a 3,000 to $5,000 \mathrm{ft}(914$ to $1,524 \mathrm{~m})$ well on the downthrown side of the Hubbell springs fault west of its intersection with the Tijeras fault. The location of this well should be selected on the basis of reliable seismic data in order to avoid drilling through the fault into the upthrown, impermeable rocks. A high angle fault dipping west at about $70^{\circ}$ would be intersected at about $5,400 \mathrm{ft}(1,646 \mathrm{~m})$ in a well located $2,000 \mathrm{ft}(610 \mathrm{~m})$ away from its surface expression. A $45^{\circ}$ fault would be intersected by a well drilled one mile $(1.6 \mathrm{~km})$ away at $5,280 \mathrm{ft}(1,609 \mathrm{~m})$.

The second drilling program should come only after the results of the seismic effort is analyzed. If seismic data shows the valley fill beds to exceed $8,000 \mathrm{ft}(2,438 \mathrm{~m})$ in thickness in the technical, operations, and administration areas of the base, one or more wells should be drilled to determine the producibilities of Btu's contained in the thermal groundwater at these depths. Obviously, the thicker the valley fill aquifer is, the higher the temperatures will be at depth, and the more valuable the resource. It is important to recognize that one well supplying $800 \mathrm{gpm}(50 \mathrm{l} / \mathrm{s})$ of $410^{\circ} \mathrm{F}\left(210^{\circ} \mathrm{C}\right)$ water would meet 85 percent 
of Kirtland's average energy demand (E. R. Hoover, this report, Appendix B). With normal temperature gradients, this well would be 18,000 to $20,000 \mathrm{ft}(5,486$ to $6,096 \mathrm{~m})$ deep. It is just as important to recognize that a series of shallower wells, though producing fewer Btu's, might be a very inexpensive method to meet the energy demands of specific buildings or special applications.

of the two drilling programs described, the second, involving drilling wells into a thick aquifer, is preferred. Although more expensive because of the necessary acquisition of additional geophysical data and drilling of deeper wells, its success is more assured. The aquifer is known to be saturated with hot water at depth. The major intangibles are the producibility and chemical composition of the fluids, factors that can be determined only by drilling and testing a well.

Evaluating the possibility of encountering a remnant of a major hydrothermal convection system postulated in the vicinity of the travertine deposits is intriguing, logical, and a geologically sound premise. Although assigned second priority, it warrants further examination.

\section{Costs}

Costs to drill and complete hot water wells should be less than $\$ 40 / \mathrm{ft}(\$ 131 / \mathrm{m})$ for wells less than $5,000 \mathrm{ft}(914 \mathrm{~m})$ deep; less than $\$ 100 / \mathrm{ft}(\$ 328 / \mathrm{m})$ for wells less than $10,000 \mathrm{ft}(3,281 \mathrm{~m})$ deep; an average $\$ 115 / \mathrm{ft}(\$ 377 / \mathrm{m})$ for wells between 10,000 to $12,499 \mathrm{ft}(3,281$ to $3,810 \mathrm{~m})$ deep; an average $\$ 143 / \mathrm{ft}(\$ 469 / \mathrm{m})$ for wells between 12,500 to $14,999 \mathrm{ft}$ $(3,810$ to $4,572 \mathrm{~m})$ deep; an average $\$ 198 / \mathrm{ft}(\$ 650 / \mathrm{m})$ for wells between 15,000 to 17,499 ft $(4,572$ to $5,334 \mathrm{~m})$ deep; and an average of $\$ 238 / \mathrm{ft}$ $(\$ 781 / \mathrm{m})$ for wells drilled 17,500 to $19,999 \mathrm{ft}(5,334$ to $6,096 \mathrm{~m})$ deep, based on 1980 costs to drill and complete oil and gas wells (Oil and Gas Journal, June 1, 1981).

These are average costs to produce "to the tanks," that would include rig costs, casing, tubing, pump, and other equipment. Based on these estimates, a $10,000 \mathrm{ft}(3,281 \mathrm{~m})$ well would cost $\$ 1$ million, a $15,000 \mathrm{ft}(4,572 \mathrm{~m})$ well would cost about $\$ 2.25 \mathrm{million}$, and a $20,000 \mathrm{ft}$ $(6,096 \mathrm{~m})$ well would cost about $\$ 4.75 \mathrm{million}$ to tie to a distribution system. Non-productive wells would cost considerably less, as there would be no completion costs involved.

If deep hot water wells are successfully completed, the operators should be aware of the probable requirement for water reinjection wells. Groundwater from depths below 4,000 ft $(1,219 \mathrm{~m})$ will probably be saline or mineralized to the extent that it must be isolated from the fresh water part of the aquifer. Reinjection wells would probably not be drilled to the same depth as the producing well, as the major consideration is to reinject a "reasonable" distance below the base of the fresh water interface of the aquifer.

\section{Cost Benefits}

E. R. Hoover (this report, Appendix B) presents an interesting and timely analysis of the benefits accruing to the user of a geothermal. resource on Kirtland AFB, particularly when compared to the use of coal as a boiler fuel. He notes that the conventional delivered energy cost for coal must include the amortized cost of capital equipment, the operating and maintenance costs, the boiler efficiency, and a cost of $\$ 2 / 10^{6} \mathrm{Btu}$ for the coal itself. If a geothermal well delivering $800 \mathrm{gpm}$ $(50 \mathrm{l} / \mathrm{s})$ of $410^{\circ} \mathrm{F}\left(210^{\circ} \mathrm{C}\right)$ delivers energy at a cost of $\$ 2 / 10^{6} \mathrm{Btu}, \$ 10$ million could be invested in the production well, a reinjection well 
(if necessary), and all other equipment before it would exceed a similar cost basis for coal. 


\section{REFERENCES}

Aiken, C. L. V., A. W. Laughlin, and F. West, Residual Bouguer Gravity Anomaly Map of New Mexico, Los Alamos Scientific Laboratory, LA-7466MAP, 1978 .

Ander, M. E., Geophysical Study of the Crust and Upper Mantle Beneath the Central Rio Grande Rift and Adjacent Great Plains and Colorado Plateau, Ph.D., Dissertation, University of New Mexico, 1980.

Bailey, R. A., and R. L. Smith, Volcanic Geology of the Jemez Mountains in Guidebook to Rio Grande Rift in New Mexico and Colorado, New Mexico Bureau of Mines and Mineral Resources, Circular 163, 1978.

Baltz, E. H., Resume of Rio Grande Depression in Northcentral New Mexico in Guidebook to the Rio Grande Rift in New Mexico and Colorado, New Mexico Bureau of Mines and Mineral Resources, Circular 163, 1978.

Bargar, K. E., Geology and Thermal History of Mammoth Hot Springs, Yellowstone National Park, Wyoming, U. S. Geological Survey, Bulletin 1444,1978 .

Bartel, L. C., C. W. Ray, R. D. Jacobson, and P. M. Drozda, Use of CSAMT Technique to Map a Fault on Kirtland Air Force Base in Geothermal Studies at Kirtland Air Force Base, New Mexico, Appendix A, Sandia National Laboratories, SAND81-0852, May 1981.

Birch, F. S., Geophysical Evaluation of Basin Hydrologic Characteristics in the Central Rio Grande, U. S. Geological Survey, Albuquerque, Unpublished Report, Contract No. 14-08-00001-17879, 1980.

Bryan, K., Geology and Ground water Conditions of the Rio Grande Depression in Colorado and New Mexico: Washington, Regional Planning, pt. 6, Rio Grande Joint Investigations in the Upper Rio Grande Basin, Natural Resources Committee, V. 1, Pt. 2, Sec. 1, 1938.

Chapin, C. E., Evolution of the Rio Grande Rift: A Summary in Rio Grande Rift: Tectonics and Magmatism, America Geophysical Union, Washington, 1979.

Chapin, C. E., The Rio Grande Rift, Pt. 1: Modifications and Additions, New Mexico Geological Society, Guidebook 22nd, Field Conference, 1971.

Chapin, C. E., R. M. Chamberlin, G. R. Osborn, D. W. White, and A. R. Sanford, Exploration Framework of the Socorro Geothermal Area, New Mexico in Field Guide to Selected Cauldrons and Mining Districts of the Datil-Mogollon Volcanic Field New Mexico, New Mexico Geological Society, Special Publication, No. 7, 1978.

Chapin, C. E., and W. R. Seager, Evolution of the Rio Grande Rift in the Socorro and Las Cruces Areas in New Mexico Geological Society, Guidebook, 26 th Field Conference, 1975.

Cordell, L. E., Sedimentary Facies and Gravity Anomaly Across Master Faults of the Rio Grande Rift in New Mexico, Geology, V. 7, No. 4, April 1979.

Cordell, L. E., Regional Geophysical setting of the Rio Grande Rift, Geological Society of America, Bulletin, V. 89, No. 7, July 1978 A. 
Cordell, L. E., Gravity Profile Along Tramway Road in Guidebook to the Rio Grande Rift in New Mexico and Colorado, New Mexico Bureau of Mines and Mineral Resources, Circular 163, 1978B.

Cordell, L. E., Aeromagnetic and Gravity Studies of the Rio Grande Graben in New Mexico Between Belen and Pilar in Tectonic and Mineral Resources of Southwestern New Mexico, New Mexico Geological Society, Special Publication No. 6, 1976.

Cordell, L. E., G. R. Keller, and T. G. Hildenbrand, Complete Bouguer Gravity Anomaly Map of the Rio Grande Rift, U. S. Geological Survey, Open File Report 78-958, 1978.

Feth, J. H., and I. Barnes, Spring-Deposited Travertine in Eleven Western States, U. S. Geological Survey, Water-Resources Investigations 79-35, Open File Report, 1979.

Grant, P. R., Jr., ENERGYtic New Mexico...The Power State, Second Edition, Albuquerque Industrial Development Service, Inc., 1977.

Hanny, J. A., and B. C. Lunis, Editor's, New Mexico Hydrothermal Commercialization Baseline, EG\&G Idaho, Inc., 1979.

Herrick, C. L., The Geology of the San Pedro and the Albuquerque Districts, University of New Mexico Bulletin 21, Geological Series, V. 1, No. 4, 1898.

Herrick, C. L., and D. W. Johnson, The Geology of the Albuquerque Sheet, University of New Mexico Bulletin 23, Geological Series, V. 2, Pt. 1, No. 1, 1900 .

Icerman, L., A. Starkey, and N. Trentman, State Coupled Low Temperature Geothermal Resource Assessment Program, FY1979, New Mexico Energy Research and Development Program, EMD 2-66-2211, New Mexico Energy and Minerals Department, 1980.

Jaksha, L. H., J. Locke, and H. J. Gebhart, Microearthquakes Near the Albuquerque Volcanoes, New Mexico, U. S. Geological Survey, (Albuquerque Seismological Laboratory), Unpublished Report, March 1980.

Jiracek, G. R., M. E. Ander, and I. K. Reddy, Magnetotelluric Profiling Across the Rio Grande Rift CoCORP Study Area in New Mexico in 1978 International Symposium on the Rio Grande Rift, Program and Ābstracts, LA-7487-C, Los Alamos, 1978.

Kauffman, D., and A. V. Houghten, Engineering and Economic Evlauation of Direct Hot-Water Geothermal Energy Applications on the University of New Mexico Campus, DOE/ID/12048-4, Bureau of Engineering Research, University of New Mexico, 1980.

Kauffman, D., and A. V. Houghton, Low Temperature Geothermal Energy Applications in the Albuquerque Area, New Mexico Energy Research and Development Program, EMD 78-2122, New Mexico Energy and Minerals Department, 1979.

Kelley, V. C., Geology of Albuquerque Basin, New Mexico, New Mexico Bureau of Mines and Mineral Resources, Memoir 33, 1977.

Kelley, V. C., Albuquerque-Its Mountains, Valley, Water and Volcanoes, New Mexico Bureau of Mines and Mineral Resources, Scenic Trip No. 9, Revised, 1974 . 
Kelley, V. C., Tectonics of the Rio Grande Depression of Central New Mexico in New Mexico Geological Society Guidebook 3rd Field Conference, Rio Grande Country, 1952 .

Kelley, V. C., and S. A. Northrop, Geology of the Sandia Mountains and Vicinity, New Mexico, New Mexico Bureau of Mines and Mineral Resources, Memoir 29, 1975.

Kelly, T. E., Reconnaissance Investigation of Ground water in the Rio Grande Drainage Basin-With Special Emphasis on Saline Ground-Water Resources, U. S. Geological Survey Hydrological Investigation, Atlas $\mathrm{HA}-510,1974$.

Kottlowski, F. E., Reconnaissance of Commercial High-calcium Limestones in New Mexico, New Mexico Bureau of Mines and Mineral Resources, Circular 60,1962 .

Lisenbee, A. L., L. A. Woodward, and J. R. Connolly, Tijeras-Canoncito Fault System-A Major Zone of Recurrent Movement in Northcentral New Mexico in New Mexico Geological Society Guidebook, 30th Annual Field Conference, Santa Fe County, 1979.

Luedke, R. G., and R. L. Smith, Map Showing Distribution, Composition, and Age of Late Cenozoic Volcanic Centers in Arizona and New Mexico, U. S. Geological Survey, Map I-1091-A, 1978.

Machette, M. N., Preliminary Geologic Map of the Socorro $1^{\circ} \times 2^{\circ}$ Quadrangle, New Mexico, U. S. Geological Survey, Open File Report $78-607,1978$.

Mahoney, M., S. G. Wells, and G. R. Jiracek, Evaluation of the Geothermal Potential of the Truth or Consequences Area, New Mexico, Abstracts, 29th Annual Meeting, Rocky Mountain Section of the American Association of Petroleum Geologists, 1981.

Marlin, J. M., R. Cunniff, P. McDevitt, K. Nowotny, and P. O'Dea, Regional Operations Research Program for Commercialization of Geothermal Energy in the Rocky Mountain Basin and Range, New Mexico Energy Research and Development Program, EMD 78-2236, New Mexico Energy and Minerals Department, 1980.

Morgan, P., V. Harder, P. Daggett, and C. A. Swanberg, A Model for the Origin and Distribution of Low Temperature Geothermal Resources in the Rio Grande Rift, Southern Rocky Mountain Complex, Abstracts, 29th Annual Meeting, Rocky Mountain Section of the American Association of Petroleum Geologists, 1981 .

Morgan, P., and P. H. Daggett, Active and Passive Seismic Studies of Geothermal Resources in New Mexico and Investigations of Earthquake Hazards to Geothermal Development, New Mexico Energy Research and. Development-Program, EMD 77-2203, New Mexico Energy and Minerals Department, 1980.

Myers, D. A., and E. J. McKay, Geologic Map of the North End of the Manzano Mountains, Tijeras and Sedillo Quadrangles, Bernalillo County, New Mexico, U. S. Geological Survey Map I-968, 1976.

Myers, D. A., and E. J. McKay, Geologic Map of the Mount Washington Quadrangle, Bernalillo and Valencia Counties, New Mexico, U. S. Geological Survey Map GQ 886, 1970. 
Newton, C. A., D. J. Cash, K. H. Olsen, and E. F. Homuth, Los Alamos Scientific Laboratory Seismic Programs in the Vicinity of Los Alamos, New Mexico, LA-6406-MS, Los Alamos, 1976.

Northrop, S. A., New Mexico's Earthquake History 1849-1975 in Tectonics and Mineral Resources of Southwestern North America, New Mexico Geological Society, Special Publication 6, 1976.

Parker, M., and G. R. Jiracek, Evaluation of Geothermal Potential, Albuquerque Area, New Mexico, Abstracts, 29th Annual Meeting, Rocky Mountain Section of the American Association of Petroleum Geologists, April 1981.

Reiche, P., Geology of the Manzanita and North Manzano Mountains, New Mexico, Bulletin, Geology Society of America, Vol. 60, July 1949.

Reilinger, R., J. Oliver, L. Brown, A. Sanford, and E. Balazs, New Measurement of Crustal Doming Over the Socorro Magma Body, New Mexico, Geology, V. 8, June 1980.

Reiter, M., C. Shearer, and C. L. Edwards, Geothermal Anomalies Along the Rio Grande Rift in New Mexico, Geology, V. 6, 1978.

Reiter, M., C. L. Edwards, H. Hartman, and C. Weidman, Terrestrial Heat Flow Along the Rio Grande Rift, New Mexico and Southern Colorado, Geological Society of America, Bulletin, V. 86, No. 6, 1975.

Riddle, L., and B. Grant, Geothermal studies at Kirtland Air Force Base, Albuquerque, New Mexico, Sandia National Laboratories, SAND81-0852, May 1981 .

Rodriguez, P., G. Scudella, and D. Fedor, New Mexico Geothermal Commercialization Planning, Semi-Annual Progress Report January 1, 1979-June 30, 1979, DOE/ID/12017-1, New Mexico Energy and Minerals Department, 1979.

Sanford, A. R., Characteristics of Rio Grande Rift in Vicinity of Socorro, New Mexico from Geophysical Studies in Guidebook in the Rio Grande Rift in New Mexico and Colorado, New Mexico Bureau of Mines and Mineral Resources, Circular 163, 1978.

Sanford, A. R., and J. Schlue, Seismic Exploration for Shallow Magma Bodies in the Vicinity of Socorro, New Mexico, New Mexico Energy Research and Development Program, EMD 76-263, New Mexico Energy and Minerals Department, 1979.

Sheriff, R. E., Encyclopedic Dictionary of Exploration Geophysics, Society of Exploration Geophysicists, 1973.

Slack, P. B., and J. A. Campbell, Structural Geology of the Rio Puerco Fault zone and its Relationship to Central New Mexico Tectonics in Tectonics and Mineral Resources of Southwestern New Mexico, New Mexico Geological Society, Special Publication 6, 1976.

Smith, R. L., R. A. Bailey, and S. L. Russell, The Volcanic Evolution of the Jemez Mountains and its Relationship to the Rio Grande Rift in 1978 International Symposium on the Rio Grande Rift, Program and Abstracts, LA-7487-C, Los Alamos, 1978.

Starkey, A., and T. G. Bebhard, Comprehensive Planning for the Development of Geothermal Energy in Las Cruces and Dona Ana County, New Mexico, New Mexico Energy Research and Development Program, EMD 2-68-2203, New Mexico Energy and Minerals Department, 1980. 
Swanberg, C. A., and P. Morgan, Geothermal Studies in the Albuquerque Area, New Mexico, New Mexico Energy and Minerals Department, Contract EMD 78-2135, May 1980.

Titus, F. B., Jr., Geology and Ground-water Conditions in Eastern Valencia County, New Mexico, New Mexico Bureau of Mines and Mineral Resources, Bulletin 41, 1963.

Towle, J. N., New Evidence for Magmatic Intrusion Beneath the Rio Grande Rift, New Mexico, Geological Society of America Bulletin, Part I, V. 91, October 1980 .

Tweto, o., Tectonic Map of the Rio Grande Rift System in Colorado, U. S. Geological Survey, Open File Report 77-750, 1977.

U. S. Army Corps of Engineers, Albuquerque Greater Urban Area, Urban Studies Program, Water Supply, Appendix III, September 1979.

U. S. Department of Commerce, National Oceanic and Atmospheric Administration, Geothermal Resources in New Mexico, (Map, Scale 1:500,000), 1980 .

Woodward, L. A., J. F. Callender, and R. E. Zilinski, Tectonic Map of the Rio Grande Rift, New Mexico, Geological Society of America, Map and Chart Series \#MC-11, 1975.

Wyant, D. J., and A. Olson, Preliminary Geologic Map of the Albuquerque $1^{\circ} \times 2^{\circ}$ Quadrangle, Northwestern New Mexico, U. S. Geological Survey, Open File Report 78-467, 1978. 
APPENDIX A

GRAVITY STUDY ON KIRTLAND AIR FORCE BASE

by

Mark Parker

March 12, 1981 
- 


\title{
APPENDIX A
}

\author{
GRAVITY STUDY ON KIRTLAND AIR FORCE BASE
}

\author{
INTRODUCTION
}

Gravity measurements have been made along six profiles on Kirtland Air Force Base; three are in an east-west direction and three trend approximately southeast-northwest (see Plate 1 and Figure 3). Station spacing is generally $0.2 \mathrm{mi}$ but was reduced to 0.1 or $0.05 \mathrm{mi}$ in the vicinity of subsurface fault scarps so that they could be more accurately located.

Measurements were made using the University of New Mexico Geology Department's Worden Model 125 gravimeter. Horizontal and vertical cóntrol was facilitated with the aid of General Site Maps provided by Kirtland AFB's Civil Engineering Department. These detailed topographic maps are drawn to a scale of $I^{\prime \prime}=200^{\circ}$ and with a contour interval of 2 feet.

The field data were reduced to yield values of free-air anomaly (FAA) and complete Bouguer anomaly (CBA). Station 1, located along Magazine Road at the east driveway of the Solar Tower, was chosen as the base station and assigned an FAA and CBA of zero. Gravity values at all other stations are relative to Station 1. In applying the Bouguer correction, the intervening layer was assumed to be alluvium with a density of $2.0 \mathrm{gm} / \mathrm{cm}^{3}$.

It is estimated that errors in the gravity values due to inaccuracies in elevation control, instrument operation, and terrain corrections are no greater than 0.2 to $0.3 \mathrm{mGal}$ and are generally much less. The greatest errors could be expected to occur in rugged terrain (e.g., within or near Tijeras Arroyo).

\section{GRAVITY PROFILES}

The gravity profiles are shown in Figures $A-1$ to $A-6$, progressing from north to south. Marked differences in the character of these profiles, the most salient being differences in slope and the appearance on some of the profiles of sharp breaks in curvature, can be interpreted in term of subsurface structure. Changes in relative gravity along lines crossing these profiles reflect differing thicknesses of sediments along those lines and therefore provide a means of determining basement configuration.

\section{"0" Street Profile}

This northernmost profile is the longest of the six; it stretches 4.2 miles from a point 0.5 miles east of Tijeras Arroyo along the boundary between the military reservation and the Four Hills residential area, continuing westward along this boundary and then along " 0 " Street to the east-west airport runway, and projecting nearly 1.2 miles onto a vacant field which borders the runway to the north.

Along this profile, gravity values decrease steadily to the west reflecting a deepening of dense basement rocks (i.e., an increase in thickness of basin fill sediments) in this direction. In relation to the 
above-mentioned geology profile, and to several subsequent interpretations, it is important to note the absence of any slope changes at the longitude of Eubank Boulevard. It has been proposed that the Hubbell springs fault, the major rift-bounding fault west of the Manzano Mountains, continues northward into Albuquerque at roughly the longitude of Eubank Boulevard. The gravity profile shows no evidence of this but rather suggests a continuous deepening of sediments westward from the Sandia fault which lies about 2 miles to the east. (The local depression in the FAA curve is due to the sharp elevation drop at Tijeras Arroyo and is removed by the Bouguer correction. In general, the FAA reflects surface topography and the Bouguer correction removes this effect).

Also notable on this profile is a gentle flattening of the curve to the west. This lends support to the proposed listric nature of the Sandia rift-bounding fault. However, a series of minor step faults could also produce this effect.

\section{Pennsylvania Avenue and Coyote Arroyo Road Profiles}

These two profiles extend westward from near the base of the Four Hills Precambrian basement exposure. They dip much more steeply to the west than the " 0 " street profile and have higher gravity values at their eastern starting points. Both features can be related to the Four Hills basement uplift. The greater values reflect the shallowness of dense granite at the east end of these profiles and the steepness of gravity gradients reflects the steepness of the fault which bounds the Four Hills on the west. The coyote Arroyo Road profile displays a greater westward dip than the Pennsylvania Avenue profile and is probably more nearly perpendicular to the fault trace. The orientation of the Four Hills with the Tijeras Fault suggests strongly that their formation is related to fault movement. The nature of this relationship is beyond the scope of this report.

The Pennsylvania Avenue and Coyote Road profiles also display decreases in curvature at points along their length; at about 1 mile from the eastern end of the Pennsylvania Avenue profile and at about 2 miles from the eastern end of the coyote Road profile. The change in slope on these profiles is more dramatic than on the "0" street profile and may represent the position of intersection between the steeply dipping fault which bounds the Four Hills and a flatter crustal block at depth. The direction of the line which connects these two slope breaks is also that of the Tijeras fault and Four Hills alignment.

Magazine Road Profile

The Magazine Road profile begins at the east driveway of the $5 \mathrm{MW}$ Solar Tower and continues westward for 2 miles. It is the first profile that depicts a sharp break indicative of a shallow subsurface fault scarp. This break in slope coincides with a group of hills composed to a large extent of travertine deposits. Westward from this point gravity gradients become very steep, nearly equal in slope to that found on the two profiles to the north. This fact, coupled with the coincidence of the slope break with the projection of the western scarp of the Four Hills Precambrian block, suggests strongly that the basement high continues in the direction of the Four Hills, approximately south-southeast, at least to the latitude of Magazine Road. Also, the fault which forms the western boundary of this basement block appears to persist in dip and direction to Magazine Road. Discussion of the gravity profiles to the south of Magazine Road will show that this orientation of fault and basement high continues to the southern edge of the military reservation. 
An interesting feature on the Magazine Road profile is the slight gravity drop at the eastern end of the profile (at the Solar Tower). It is positioned on line with, and may be related to, the Tijeras fault trace. Time constraints and a lack of probable geothermal significance prevented a closer examination of this feature.

\section{South Fence Road and University Road Profiles}

The South Fence Road profile is 2.3 miles long, extending 0.5 miles east and 1.8 miles west of the intersection of South Fence Road with Isleta Road. The westernmost station is at the southwest corner of the military reservation. Salient on this profile is the increase in slope slightly west of the Isleta Road intersection. As on the Magazine Road profile, the gravity change coincides with a topographic ridge. This feature is also colinear with the western edge of the Four Hills Precambrian block and is almost certainly an extension of the associated fault. The relative gravity and sharpness of slope break are not as' great as at Magazine Road. Both results are explained by a thicker cover of low density material to the south. The slope of the gravity curve briefly becomes equal to that of the three previously discussed profiles but appears to flatten almost immediately. This could mean that the deep basin formed by downdropping of basement rocks west of Four Hills becomes shallower to the south in perhaps a ramp geometry. Alternatively, the decrease in slope could be the result of an enigmatic bench which extends westward into the Rio Grande rift south of the military reservation.

A short $(0.6 \mathrm{mi})$ profile was taken along University Road, which trends northwesterly from the intersection of South Fence Road with Isleta Road, to better determine the direction of the fault between where it crosses Magazine Road and where it crosses the South Fence Road. As expected, the gravity indication of the fault along University Road is on line with its trace to the north and south. The steep slope west of the slope break is the same as that of the steepest portion of the South Fence Road profile suggesting that both profiles cross the fault at nearly equal angles. The lack of any change in curvature of the University Road profile lends further support to the possibility that the deep basin west of Four Hills begins to shallow at the south end of the military base where a basement bench begins to influence structure. 


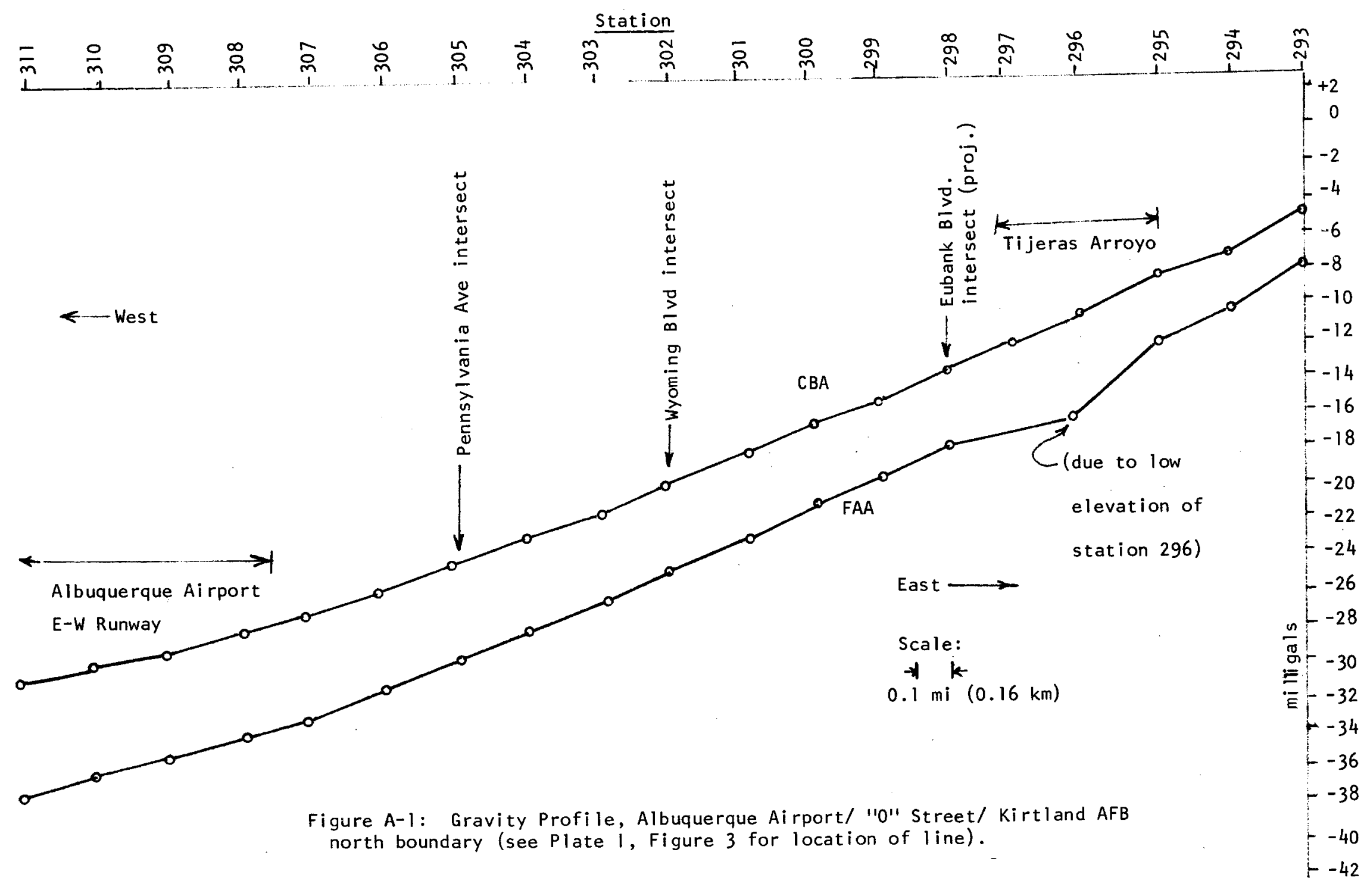




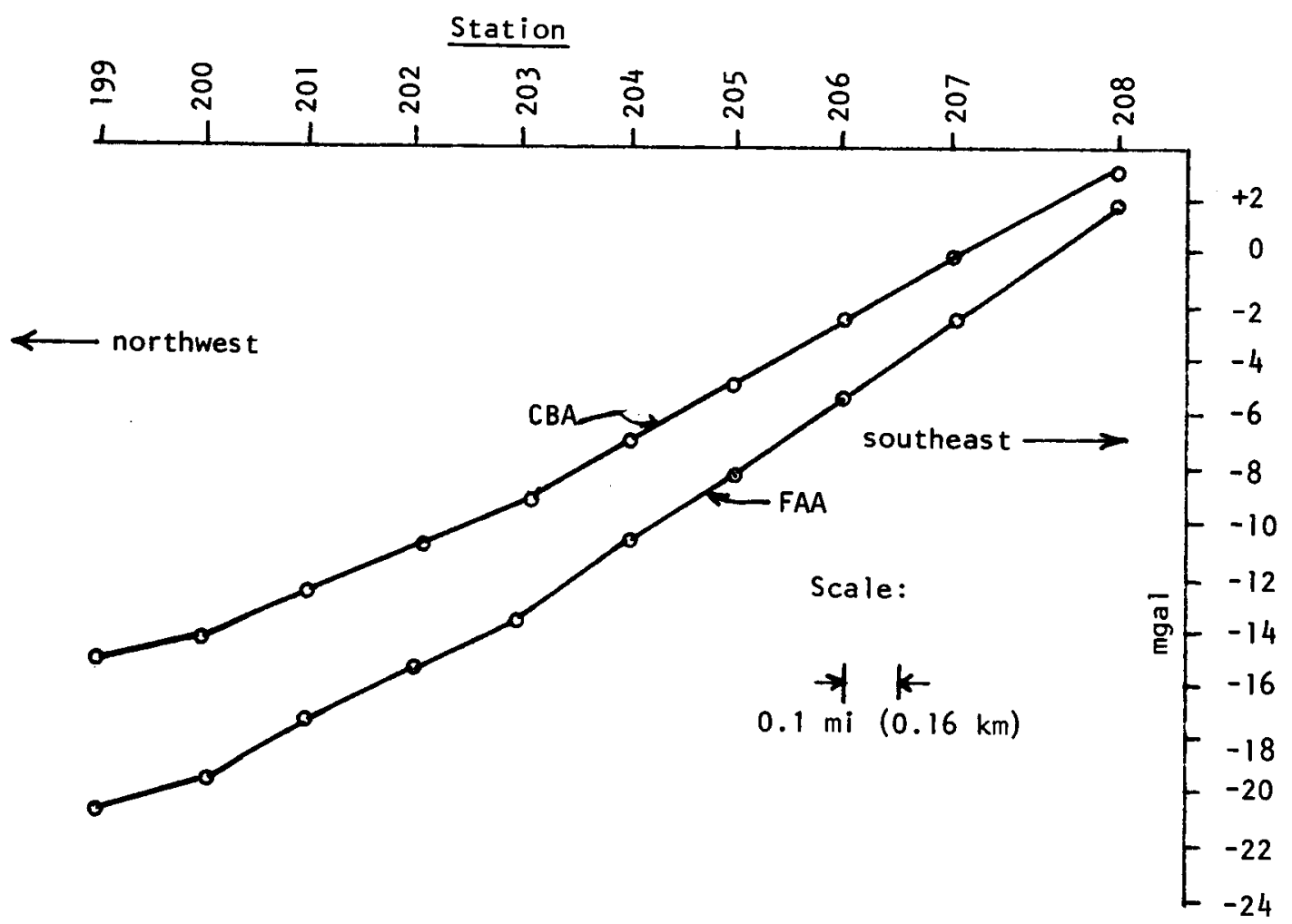

Figure A-2: Gravity Profile, Pennsylvania Ave, vicinity of Coyote Arroyo to golfcourse. 


\section{Station}
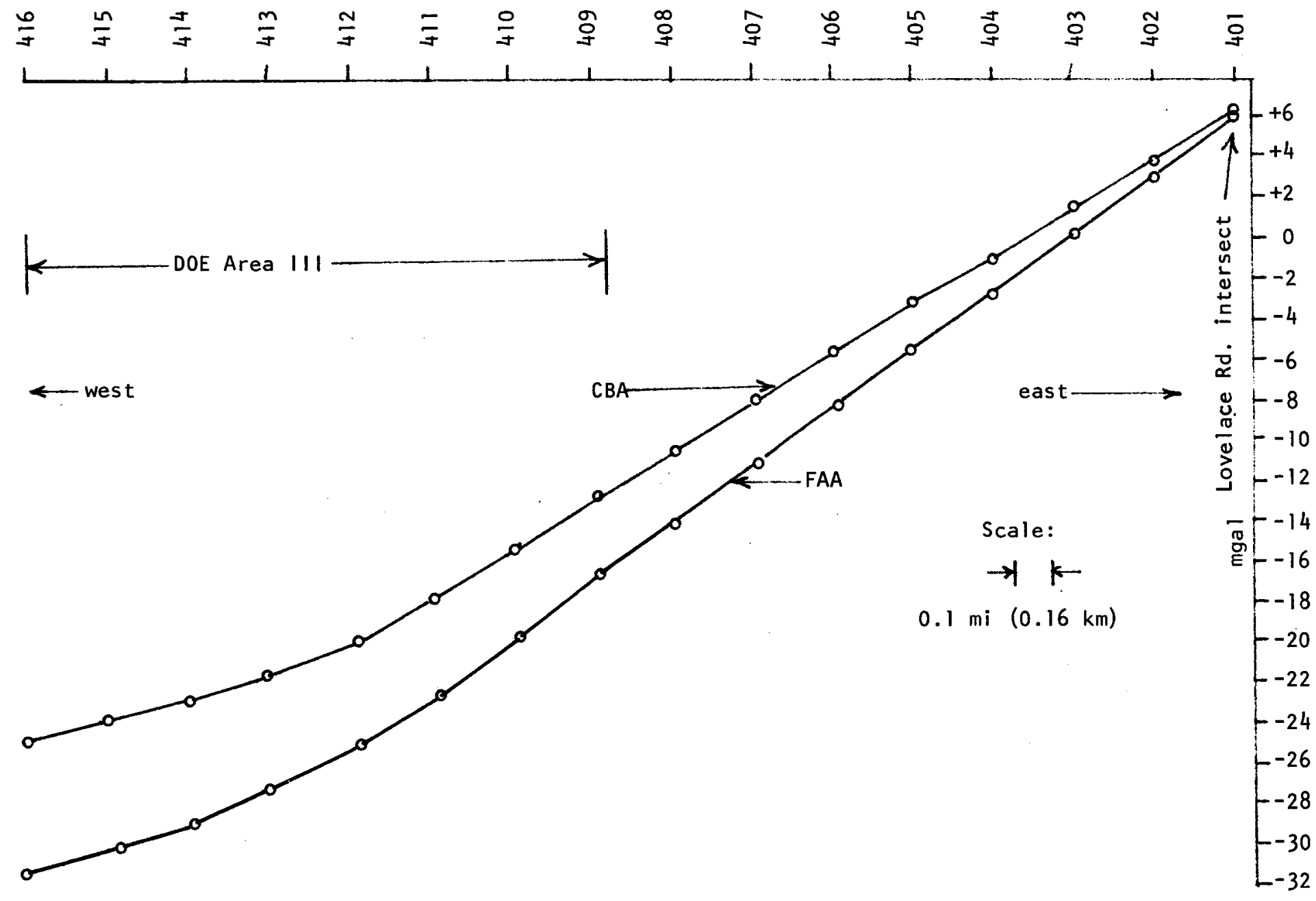

Figure A-3: Gravity Profile, Coyote Arroyo Road. Vicinity of Coyote Arroyo bridge to west boundary of UUUE Área 111 . 


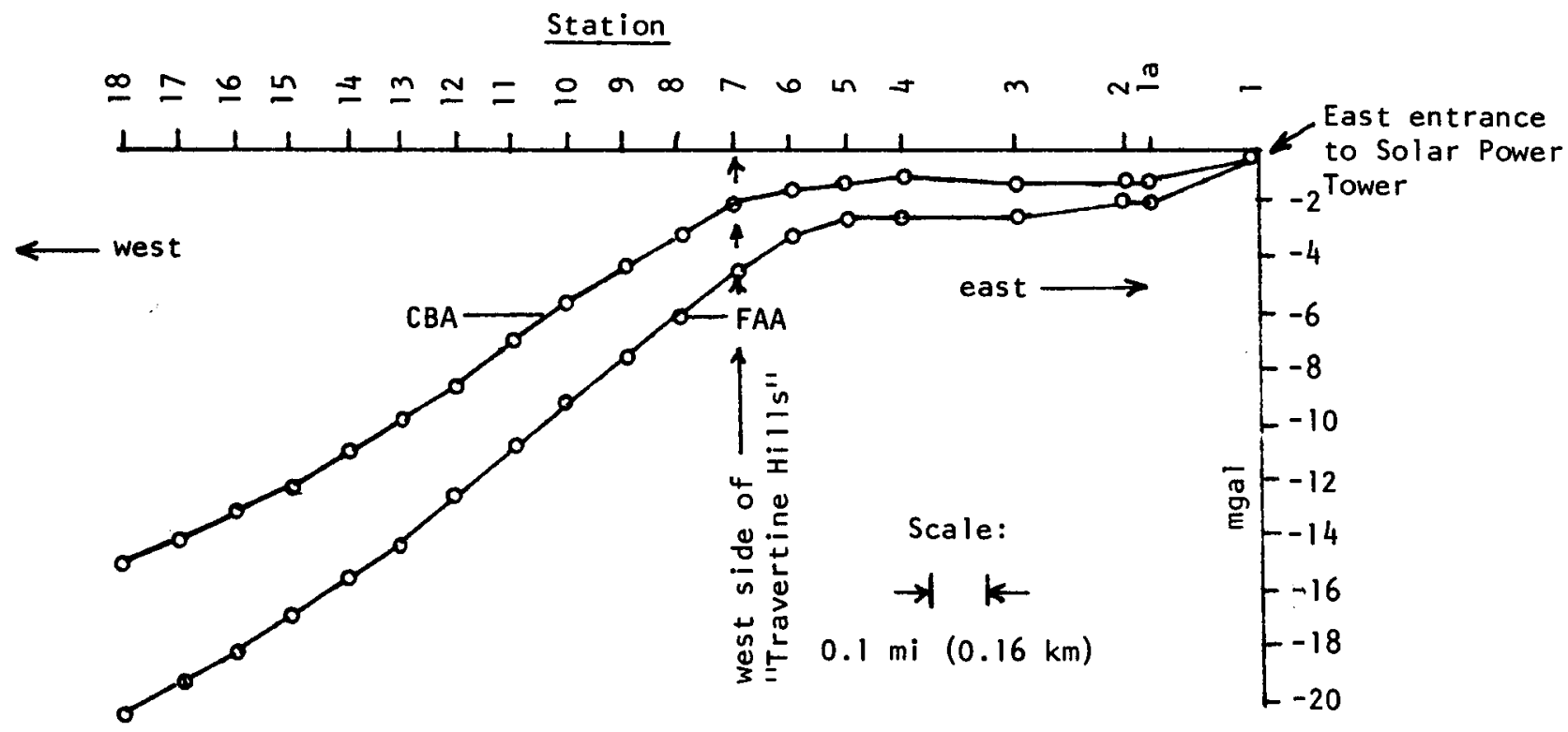

Figure A- 4: Gravity Profile, Magazine Road. Vicinity of Solar Power Tower a distance of about $2 \mathrm{mi}(3 \mathrm{~km})$ west. 


\section{Station}

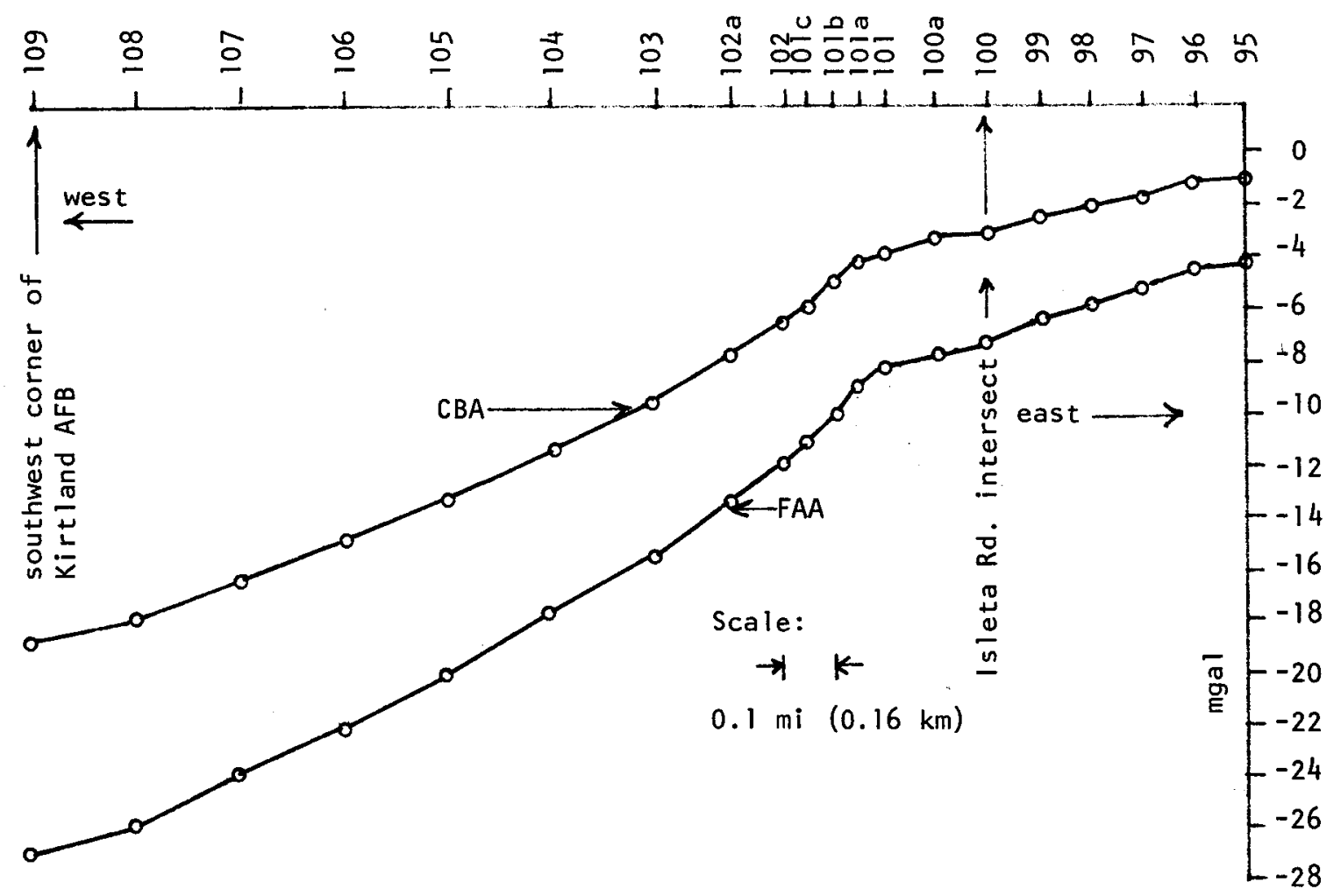

Figure A-5: Gravity Profile, South Fence Road. 


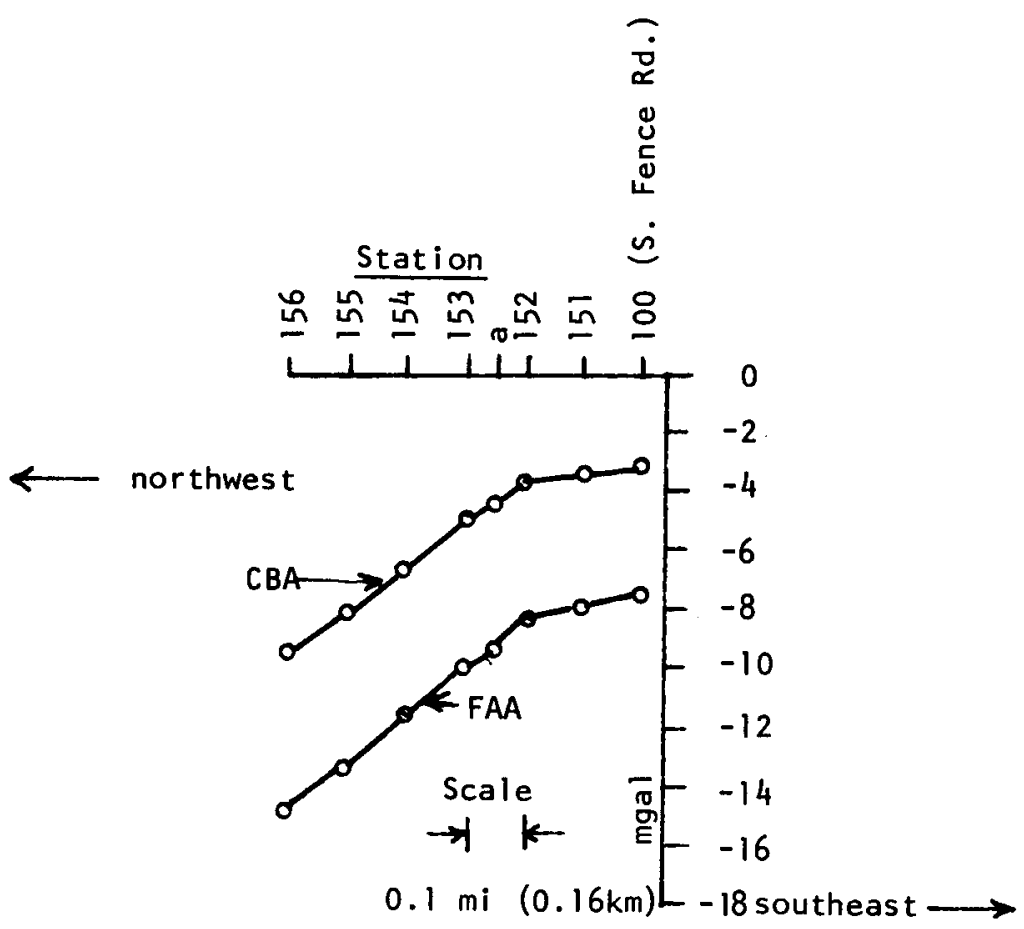

Figure A-6: Gravity Profile, University Ranch Road 
.

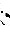




\section{APPENDIX B \\ PRELIMINARY EVALUATION OF GEOTHERMAL \\ POTENTIAL AT SANDIA}

by

E. R. Hoover

May 16,1980 
$\cdots$ 


\section{Sandia Laboratories}

date: May 16, 1980

Albuquerque. New Mexico

Livermore. California

10 :

R. K. Traeger -4740

from:

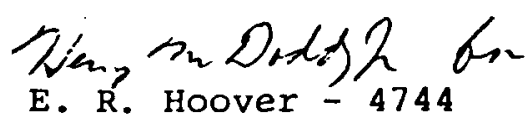

subject:

Preliminary Evaluation of Geothermal Potential at Sandia

The first step in this evaluation was to determine the heating requirements of the Area I facilities. The heating plant and distribution system are generalized in Figure 1.

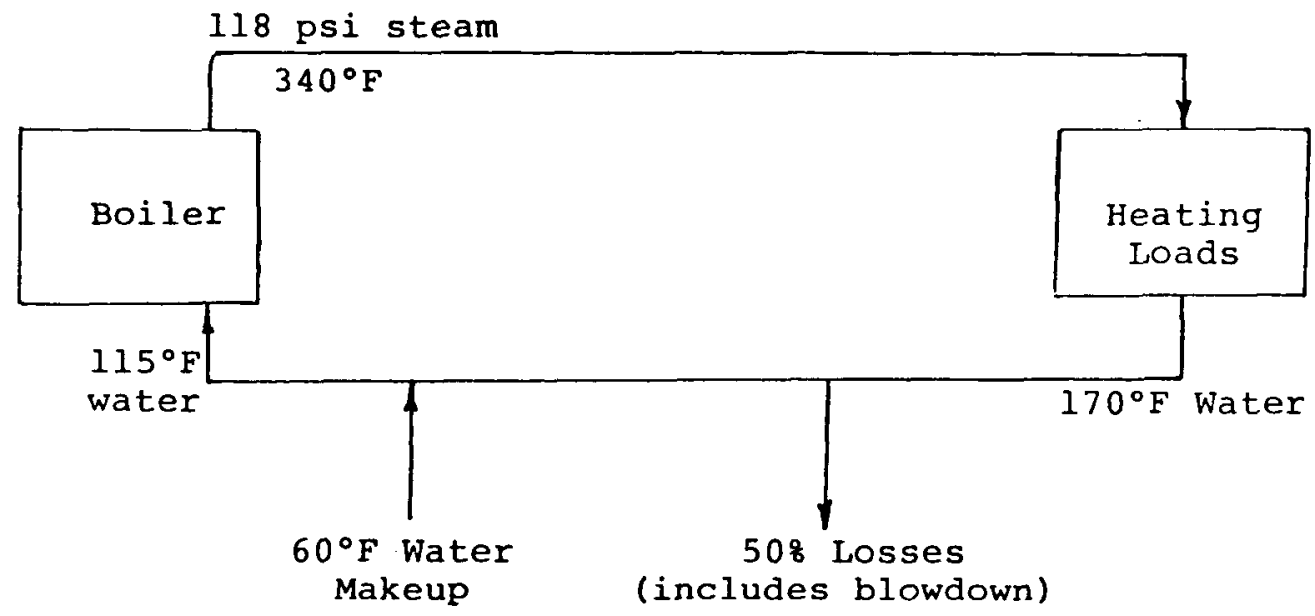

Figure 1. Overall SNLA Heating System

Currently the boiler is fired by natural gas 85 to 95 percent of the time. Whenever natural gas is not available, \#2 fuel oil is used. The average, minimum, and maximum loads are given below:

$$
\begin{aligned}
& \text { Average Steam Load }=85,000 \mathrm{lb} / \mathrm{hr} \quad 94 \times 10^{6} \mathrm{Btu} / \mathrm{hr} \\
& \text { Maximum Steam Load }=200,000 \mathrm{lb} / \mathrm{hr} \quad 221 \times 10^{6} \mathrm{Btu} / \mathrm{hr} \\
& \text { Minimum Steam Load }=60,000 \mathrm{lb} / \mathrm{hr} \quad 66 \times 10^{6} \mathrm{Btu} / \mathrm{hr}
\end{aligned}
$$

Earl Gruer in Division 36.52 indicated that much of the heating and airconditioning equipment around the labs could operate satisfactorily with steam temperatures lower than $340^{\circ} \mathrm{F}$, but the existing distribution system would probably have to be modified extensively. To avoid modifying the distribution system, which would be very expensive, the geothermal 
heating system should be capable of producing $340^{\circ} \mathrm{F}$ saturated steam.

The formation temperature in the Albuquerque area may be determined using the following expression:

$$
\mathrm{T}=60+.0175{ }^{\circ} \mathrm{D}\left({ }^{\circ} \mathrm{F}\right)
$$

where $T\left({ }^{\circ} \mathrm{F}\right)$ is formation temperature and $D(f t)$ is the well depth. Assuming we drill a 20,000 ft well, the bottomhole temperature should be approximately $410^{\circ} \mathrm{F}$. Now, if we assume the overall temperature drop in the well, and in the transmission line, will not exceed $50^{\circ} \mathrm{F}$, we should be able to deliver $360^{\circ} \mathrm{F}$ water to the hot side of a counterflow heat exchanger. Furthermore, we should be able to achieve at least a $200^{\circ} \mathrm{F}$ drop across the heat exchanger since the inlet fluid temperature on the cold side will be only $115^{\circ} \mathrm{F}$ (refer to Figure 1). If we also assume a nominal flowrate of $800 \mathrm{gpm}$, the thermal output of the well is about $80 \times 10^{6} \mathrm{Btu} / \mathrm{hr}$. This is very close to the average heating load of $94 \times 10^{6} \mathrm{Btu} / \mathrm{hr}$.

Now, if we know the 1980 cost of delivered thermal energy $(\$ / 106 \mathrm{Btu})$, we can determine the breakeven installed cost of the geothermal well, piping, pumps, heat exchange equipment, etc. The key economic assumptions are given in Table $I$.

Table I.

Economic Assumptions

$\begin{array}{lc}\text { Useful well Life } & 5,10,15 \mathrm{yr} \\ \text { Ownership } & \text { Government } \\ \text { Cost of Capital } & 108 \\ \text { Inflation Rate } & 108 \\ \text { Conv. Energy Escalation Rate } & 10 \% \\ \text { Effective Income Tax Rate } & 0 \\ \text { Investment Tax Credit } & 0 \\ \text { Annual O\&M as fraction of Installed } & 18 \\ \quad \text { Cost Insurance as fraction of } & .258 \\ \text { Annual Insur } \\ \text { Installed Cost } & 1980 \\ \text { Base Year } & 1980 \\ \text { Price Year } & 1980 \\ \text { Expenditure Year } & 1981 \\ \text { Startup year } & 858 \\ \text { Well Utilization Factor } & 595,680 \quad 10^{6} \mathrm{Btu} \\ \text { Annual Thermal Energy Delivered } & \end{array}$

The breakeven installed cost of the geothermal well and all of its associated equipment is plotted in Figure 2 as a 


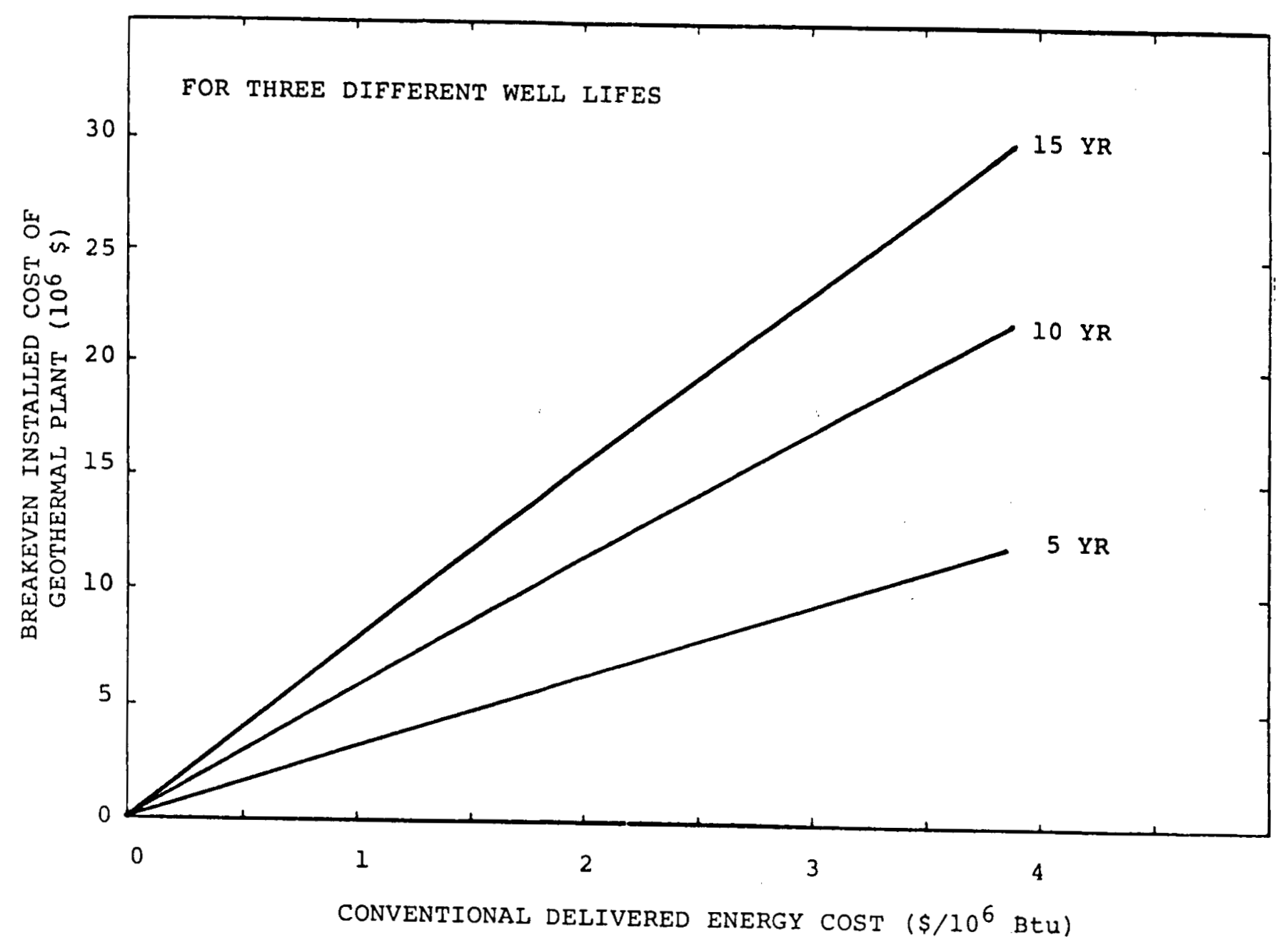

Figure 2. Breakeven Installed cost of Geothermal Plant for Three Different Lifetimes 
function of the conventional cost of the delivered thermal energy in the price years.

It is important that the conventional delivered energy cost for coal must include the amortized cost of capital equipment, the O\&M cost, and the boiler efficiency, as.well as the cost of fuel. For coal the fuel cost alone for a small heating plant may be around $\$ 2 / 10^{6}$ Btu. If we assume a geothermal well life of 10 years and $\$ 2 / 10^{6}$ Btu delivered energy cost, we can afford to spend over $\$ 10,000,000$ on the producing well, injection well if necessary, and all other equipment required. Assuming a drilling cost of $\$ 200 / \mathrm{ft}$ the producing well would cost only $\$ 4,000,000$. Under these conditions, geothermal looks very promising.

However, a more complete analysis is required before one can make any conclusive statements. If geothermal must meet $100 \%$ of the heating load at Sandia, several wells will have to be installed in order to always meet the peak load. Thus, there will be a significant amount of excess capacity that must be amortized. The coal fired boiler, on the other hand, will not be penalized as severely, since the fuel cost is a significant portion of its delivered energy cost.

Ideally, the geothermal capacity should be sized for the average load in order to maximize its utilization factor. Natural gas or fuel oil could be used in the present boiler to satisfy the peaking requirements. This may or may not be a viable option, depending on the political climate.

In summary, geothermal could be economically attractive under the right conditions and should be evaluated further when better data are available on the resource and its cost. In addition, a more detailed evaluation of the alternatives is justified.

copy to:

3600 R. W. Hunnicutt

4700 J. H. Scott

4741 S. G. Varnado

4744 H. M. Dodd 
Distribution:

HQ USAF/LEY

The Pentagon

washington, DC 20330

HQ USAF/LEE

The Pentagon

Washington, DC 20330

HQ USAF/RD

The Pentagon

Washington, DC 20330

OSAF/MIQ

The Pentagon

Washington, DC 20330

OSAF / RD

The Pentagon

Washington, DC 20330

AUL/LSE 71-249

Maxwell AFB, AL 36112

$\mathrm{HQ}$ AFSC/DE

Andrews AFB, DC 20334

HQ AFSC/SD

Andrews AFB, DC 20334

HQ AFSC/DLUM

Andrews AFB， DC 20334

HQ AFSC/DEEB

Andrews AFB, DC 20334

HQ USAFA/DE

USAF Academy, CO 80840

HQ USAFA/Library

USAF Academy, CO 80840

USAFA/DFP

USAFA Academy, CO 80840

USAFA/DFEM

USAF Academy, CO 80840

USAFA/DFCE

USAF Academy, CO 80840

HQ TAC/DE

Langley AFB, VA 23665

HQ SAC/DE

Offutt AFB, NE 68113

HQ SAC/DEPD

offutt AFB, NE 68113
HQ MAC/DE

Scott AFB， IL 62225 (3)

HQ ATC/DE

Randolph AFB, TX 78148 (3)

HQ ATC/DEE

Randolph AFB, TX 78148 (2)

HQ ATC/DEV

Randolph AFB, TX 78148 (2)

HQ AAC/DE

Elmendorf AFB, AK 99506 (3)

$\mathrm{HQ}$ AFLC/DE

Wright-Patterson AFB, OH 45433

HQ USAFE/DE

APO NeW York 09012

HQ PACAF/DE

Hickman AFB, HI 96824

AFOSR/CC

Bolling AFB, DC 20332

AFWAL/POE

Wright-Patterson AFB, OH 45433

DTIC/DDA-2

Cameron Station

Alexandria, VA 22314

OSAD (MRA\&L) /EES

The Pentagon

Washington, DC 20301

USA/CERL

Champaign, IL 61820

USA/DAEN-RDM

The Pentagon

Washington, DC 20301

USA FESA

Ft. Belvoir, VA 22060

AFIT/Library

Wright-Patterson AFB, OH 45433

AFIT/DE

Wright-Patterson AFB, OH 45433

USN NCEL

Port Hueneme, CA 93041

NAVFAC/Code 1113 (T. Ladd)

200 Stovall Street

Alexandria, VA 22332 
HQ AFESC/DEB

Tyndall AFB， FL 32403

HQ AFESC/TST

Tyndall AFB，FL 32403

HQ AFESC/RDVA

Tyndall AFB, FL 32403

HQ AFESC/RDVA

Tynda11 AFB, FL 32403

HQ AFESC/RDV

Tyndal1 AFB， FL 32403

AFATL/DLODL

(Tech Library)

Eglin AFB， FL 32542

ALO/ERTD

Department of Energy

P. O. Box 5400

Albuquerque, NM 87115

ALO/AF Liaison

Department of Energy

P. O. Box 5400

Albuquerque, NM 87115

AF Liaison

DOE/SERI Site Office

1617 Cole Bouelvard

Golden, $C O 80401$

MX RES Project office

DOE/Forrestal Building

BH-024

Washington, DC 20585

Cliff Carwile, Chief

Advanced Technology Branch

Division of Geothermal Energy

U. S. Department of Energy

Mail Station 3344

12 th and Penn NW, Room 7110

Washington, DC 20461

J. W. Salisbury

Division of Geothermal Energy

U. S. Department of Energy

Mail Station 3344

12th and Penn NW, Room 7110

Washington, DC 20461

Philip R. Grant (10)

Energy Resources Exploration, Inc.

9720-D Candelaria, NE

Albuquerque, New Mexico

87111
Dr. Larry Icerman, Director

New Mexico Energy Institute

New Mexico State University

P. O. BOX NMEI

Las Cruces, New Mexico 88001

Mr. Larry Kehoe, Secretary

New Mexico State Energy and Minerals Department

P. O. Box 2770

Santa Fe, New Mexico 87501

Geothermal Resources Council

P. O. Box 98

Davis, California 95616

Dr. Duncan Foley

University of Utah Research

Center

391-A Chipeta Way

Salt Lake City, Utah 84108

R. I. Gerson

Department of Energy

Division of Geothermal Energy

Mail Station 3344

12th and Penn, NW

washington, DC 20461

3600 R. W. Hunnicutt

4200 G. Yonas

4300 R. L. Peurifoy, Jr.

4400 A. W. Snyder

4500 E. H. Beckner

4700 J. H. Scott

4710 G. E. Brandvold

4715 R. H. Braasch

4720 D. G. Schueler

4740 R. K. Traeger

4741 J. R. Kelsey

4743 H. C. Hardee

4743 L. Riddle

4746 B. Granoff

4747 P. J. Hommert

4748 B. E. Bader

4750 V. L. Dugan

5541 W. C. Luth

8214 M. A. Pound

3141 L. J. Erickson (5)

3151 W. L. Garner (3)

3154-3 C. H. Dalin (25)

(for DOE/TIC) 